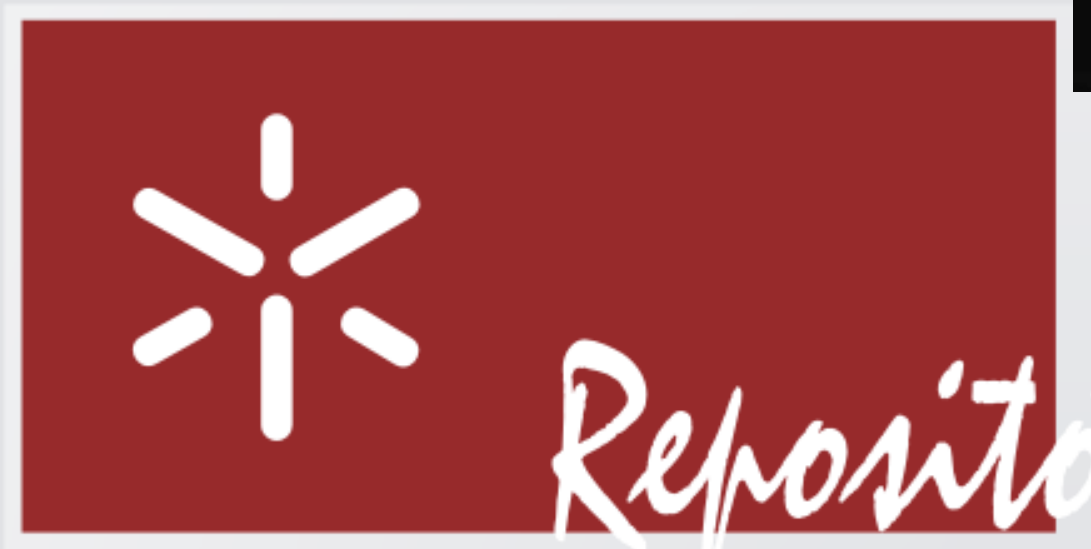

REPOSITÓRIOS INSTITUCIONAIS E DE

OBJETOS VIRTUAIS DE APRENDIZAGEM

Florianópolis, 4 de Novembro de 2009

\title{
A experiência da Universidade do Minho promovendo o acesso livre à literatura científica
}

Eloy Rodrigues

eloy@sdum.uminho.pt

http://repositorium.sdum.uminho.pt 


\section{Sumário}

- Introdução - A Universidade do Minho

- O movimento de Acesso Livre (Open Access) e os

Repositórios Institucionais

- A experiência da Universidade do Minho:

- Criação e desenvolvimento do RepositóriUM

- A Politica de Auto-Arquivo de Publicações

- Participação em projectos nacionais e internacionais 


\section{Universidade do Minho}

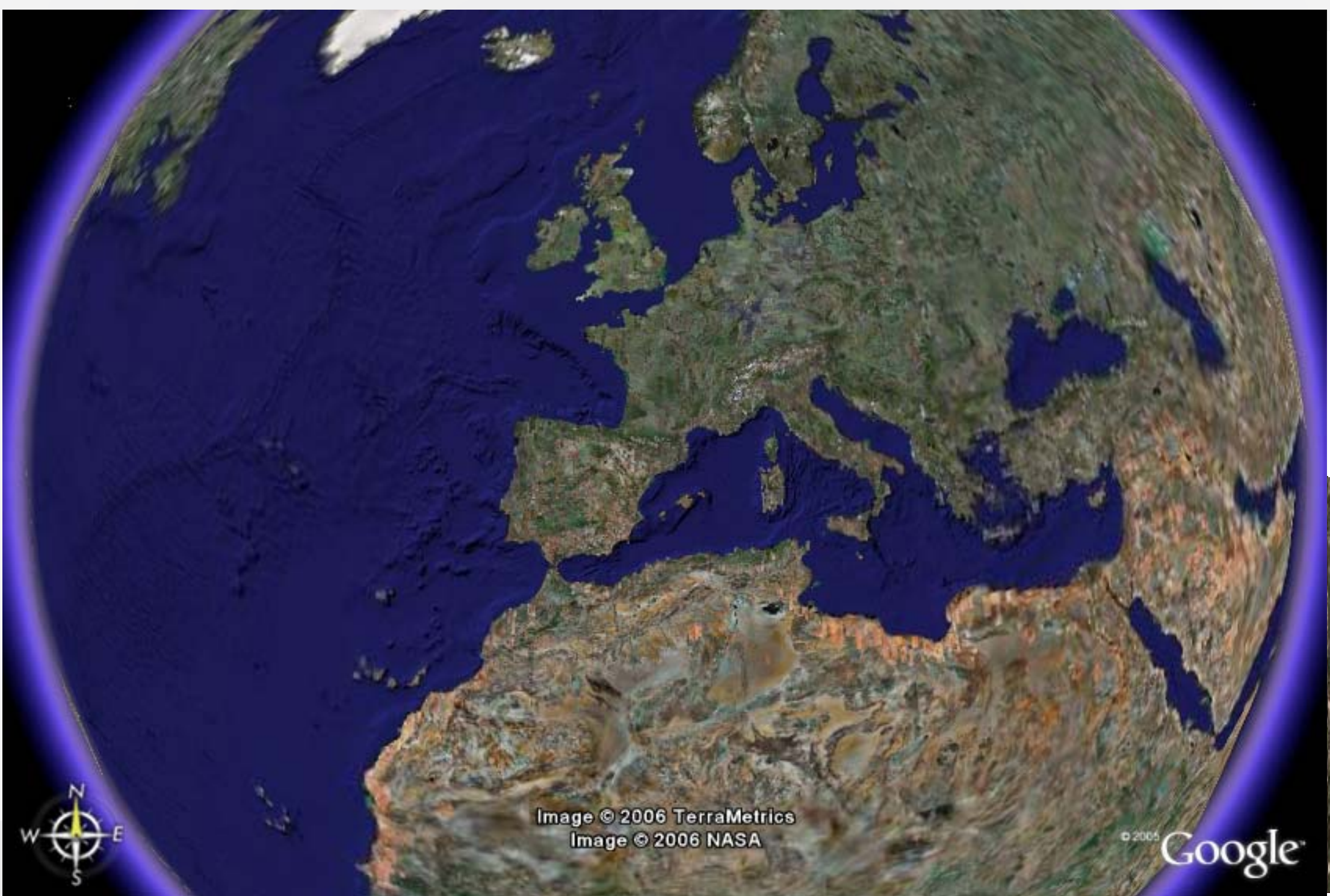

Universidade do Minho Serviços de Documentação 


\section{Introdução}

- «uma velha tradição e uma nova tecnologia convergiram para tornar possível o aparecimento de um bem público sem precedentes. A velha tradição é a boa-vontade de investigadores e cientistas publicarem os resultados da sua investigação em revistas científicas, sem qualquer remuneração, apenas em prol da investigação e difusão do conhecimento. A nova tecnologia é a Internet. $O$ benefício público que as duas possibilitam é a distribuição electrónica, a uma escala mundial, da literatura científica com revisão pelos pares, de forma gratuita e sem restrições de acesso (...)».

- Tradução de BUDAPEST OPEN ACCESS INITIATIVE [em linha]. 2002Disponível em <URL: http://www.soros.org/openaccess/read.shtml>. 


\section{A "UTOPIA" de Budapeste}

- "A distribuição mundial da literatura publicada em revistas com peer-review e o acesso completamente livre e irrestrito a essa literatura por todos os cientistas, académicos, professores, estudantes e outras mentes curiosas. A remoção das barreiras a esta literatura acelerará a investigação, enriquecerá a educação, (...), e estabelecerá as fundações para unir a humanidade num comum diálogo intelectual e procura de conhecimento." Tradução da Budapest Open Access Initiative 


\section{Evolução e marcos Open Acess}

- Origem do Universo: 14 biliões anos

- Origem da Vida na Terra: 4 biliões anos

- Origem da nossa Espécie : 200,000 anos

- Origem da Linguagem: 100-200,000 anos

- Origem da Escrita: 10,000 anos

- Origem da Imprensa: 500 anos

- Origem das Revistas Científicas: 340 anos

- Origem da Internet: $\mathbf{4 0}$ anos

- Origem da Web: 18 anos

- Origem da OAl: 10 anos 


\section{'Velhos' paradigmas}

- O uso de métricas indirectas (como o factor de impacto) para avaliar o mérito científico é o melhor que se pode fazer

- As editoras são responsáveis pela disseminação dos trabalhos científicos/académicos

- O artigo impresso é o formato do registo/arquivo científico

- Os outros investigadores têm tempo para encontrar o que vocês querem que eles conheçam.

\section{'Novos' paradigmas}

- Métricas mais ricas, mais profundas e mais abrangentes para avaliar as contribuições individuais de autores

- A disseminação efectiva da produção científica está nas mãos dos autores (por fim!)

- O formato digital será o formato de registo/arquivo oficial da ciência (já o é em várias áreas científicas).

- A menos que publique regularmente na Nature ou Science, ter 'visibilidade científica' fica nas mãos dos autores 
O que é o Open Access?

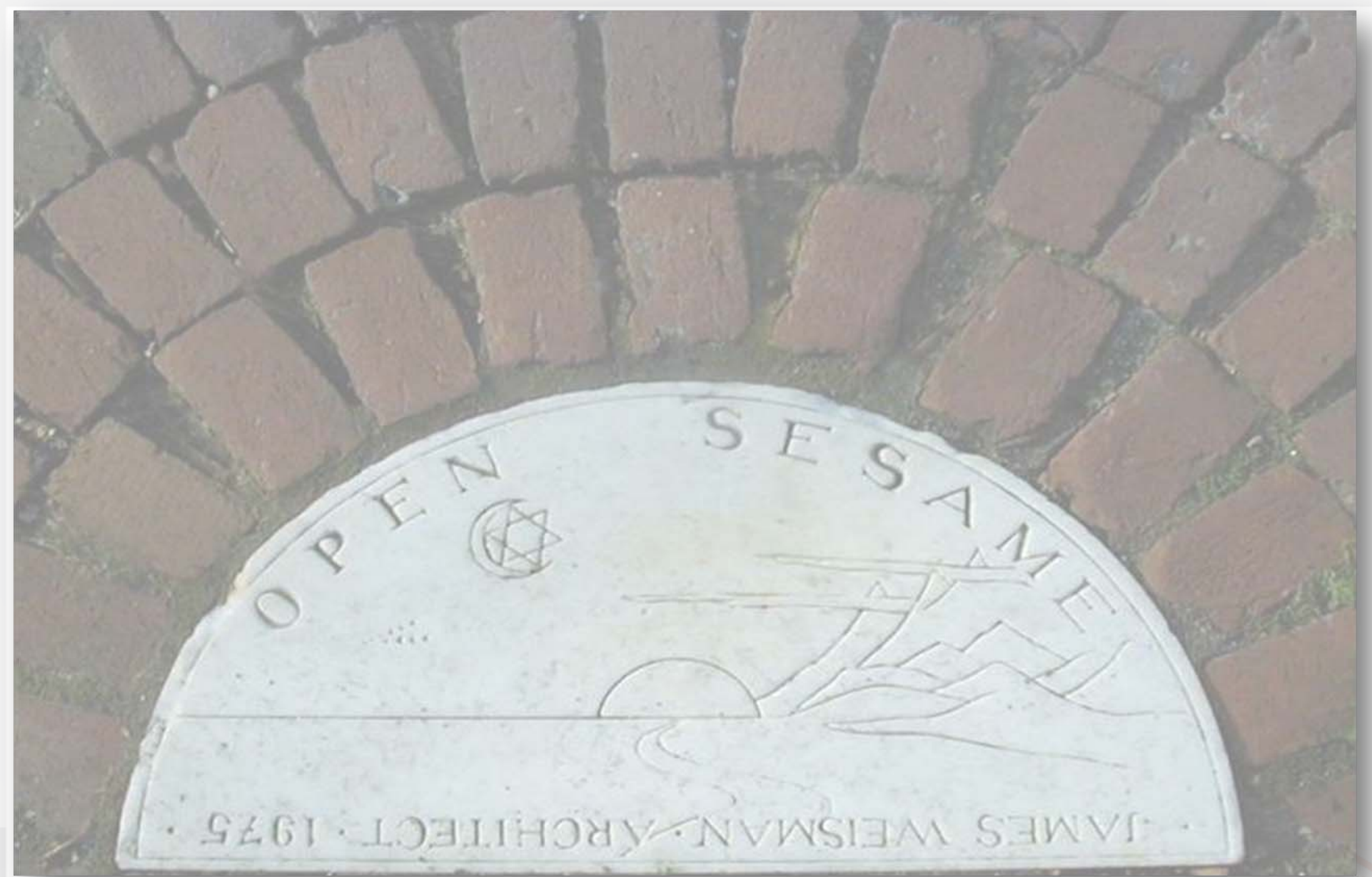



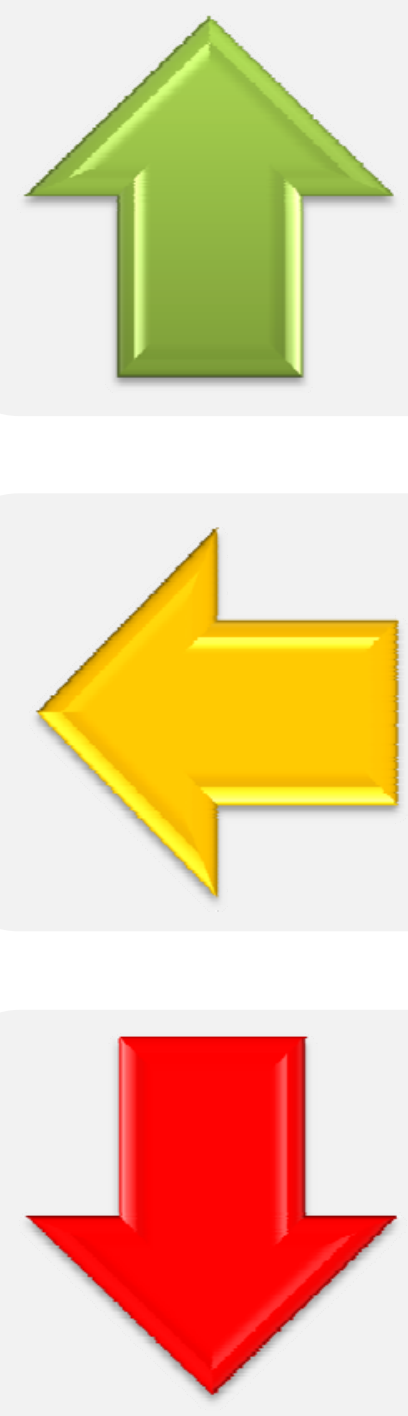

\section{Essencial:}

Aos cerca de 2.5 milhões de artigos publicados por ano, a nível mundial, em cerca de 25,000 revistas com peer-review em todas as disciplinas académicas e cientificas.

\section{Opcional: \\ A comunicações, teses e dissertações, relatórios, working papers, artigos não revistos (preprints); monografias; etc.}

\section{Não Aplicável:}

O Acesso Livre não se aplica a livros sobre os quais os autores pretendam obter receitas ou textos não académicos, como notícias ou ficção. 
O Movimento de Acesso Livre

- Causas:

- consciência das limitações e contradições do actual sistema de comunicação científica

- possibilidades tecnológicas

- Objectivos

- Maximizar o impacto da investigação, maximizando o acesso aos seus resultados

- Reassumir o controlo do sistema de comunicação da ciência 
Problemas e contradições no sistema de comunicação da ciência

- O mundo académico perdeu o controlo sobre o sistema de comunicação da ciência.

- Aumento constante dos preços dos periódicos (custo médio das assinaturas cresceu 215\% entre 1986 e 2003, nos EUA, contra $68 \%$ de inflação nesse período), acompanha um movimento de grande concentração (quase monopolista) na indústria da informação de Ciência e Tecnologia. 
Problemas e contradições no sistema de comunicação da ciência

- As barreiras ao acesso traduzem-se numa perda de eficiência do sistema de comunicação da ciência, e em limitações ao impacto e reconhecimento dos resultados alcançados pelos investigadores e as instituições onde trabalham. 
Acesso Livre porquê?

- Aumentar a visibilidade, o acesso, a utilização e o impacto dos resultados de investigação.

- Acelerar e tornar mais eficiente o progresso da ciência.

- Melhorar a monitorização, avaliação e gestão da actividade científica. 
Acesso Livre porquê?

- Ao contrário de outros autores, os investigadores e académicos publicam os resultados do seu trabalho não para obterem rendimentos (direitos de autor, royalties, etc.), mas para obterem outro tipo de recompensa: impacto da publicação.

- Os investigadores são recompensados (progressão na carreira, financiamento dos seus projectos, prémios científicos, etc.), pela sua produtividade científica, que é avaliada não apenas pela sua dimensão (quantidade), mas sobretudo pelo seu impacto (qualidade). 


\section{Acesso Limitado $=$ Impacto Limitado}

(Traduzido e adaptado de Harnad)

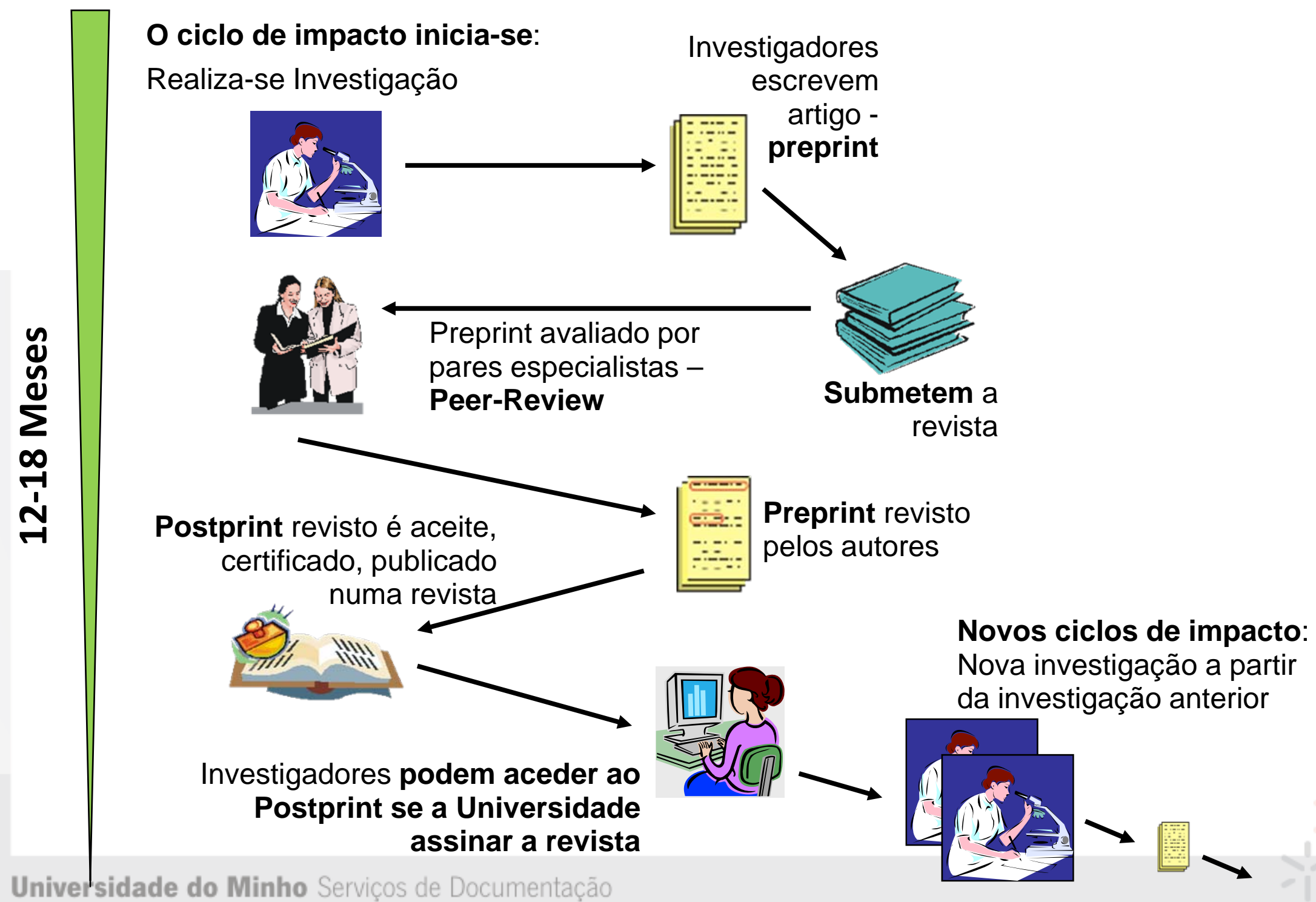



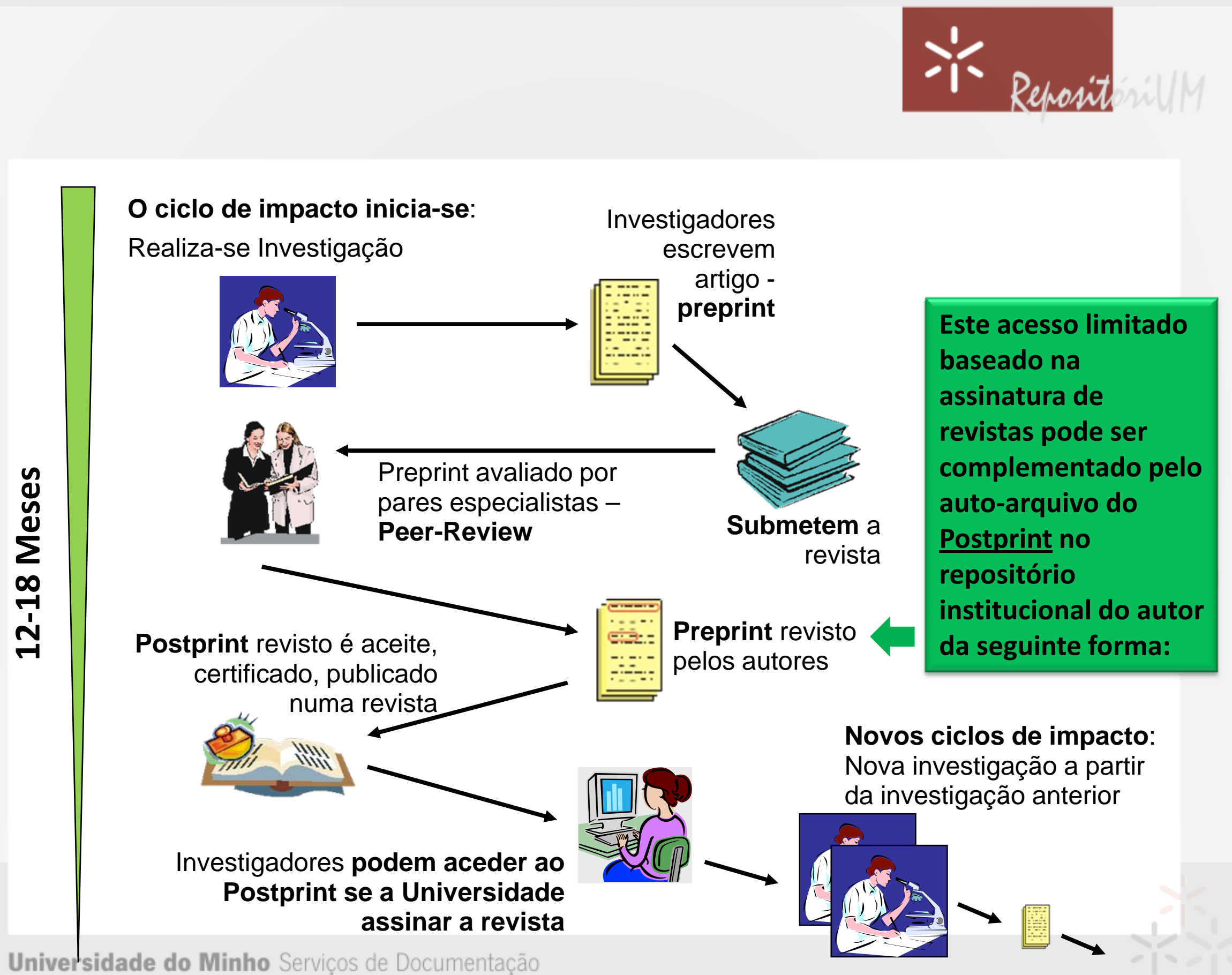
Impacto e acesso à investigação maximizado pelo "autoarquivo"

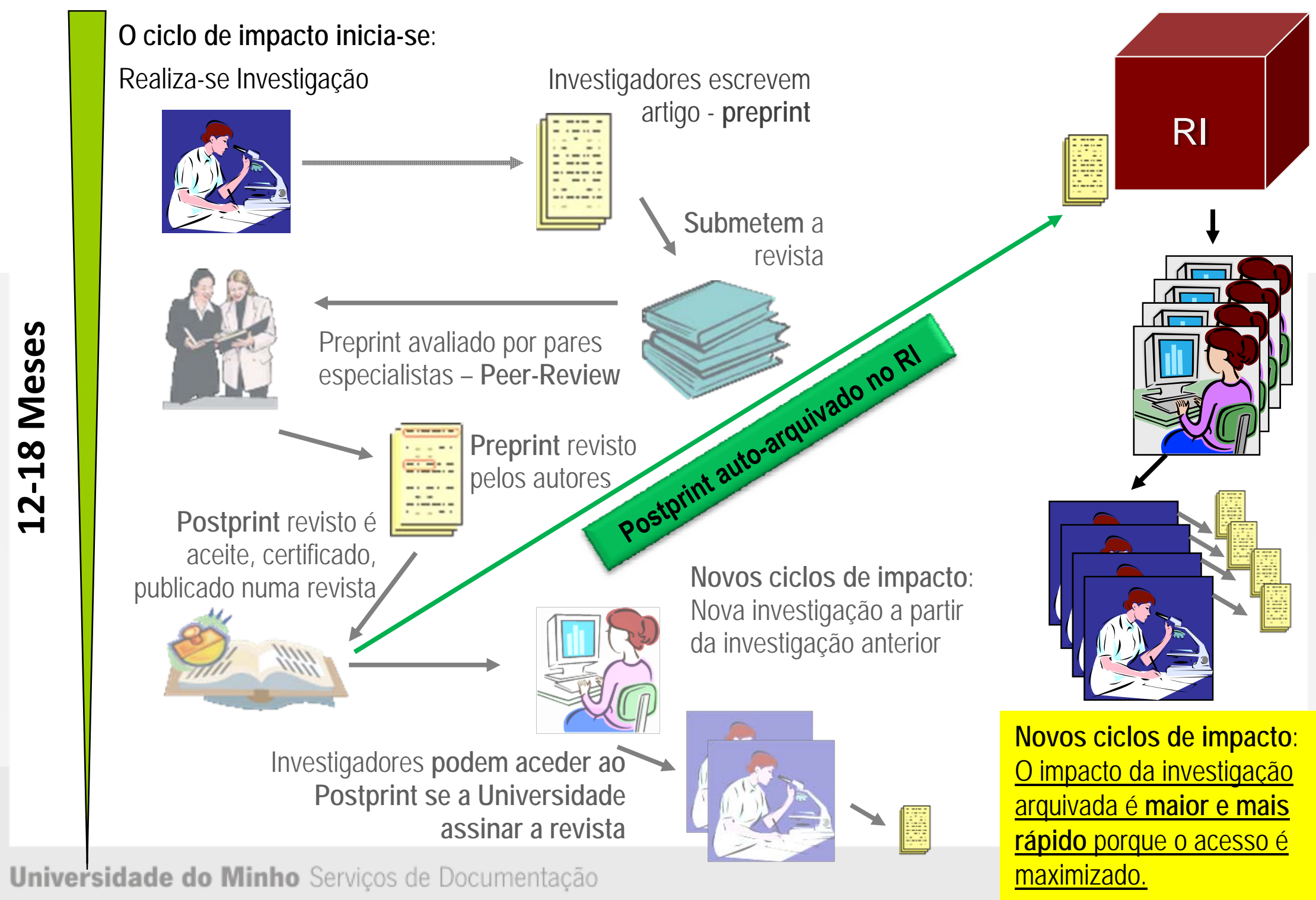




\section{Impacto dos resultados de investigação...}

\section{\% aumento citações com Acesso Livre}

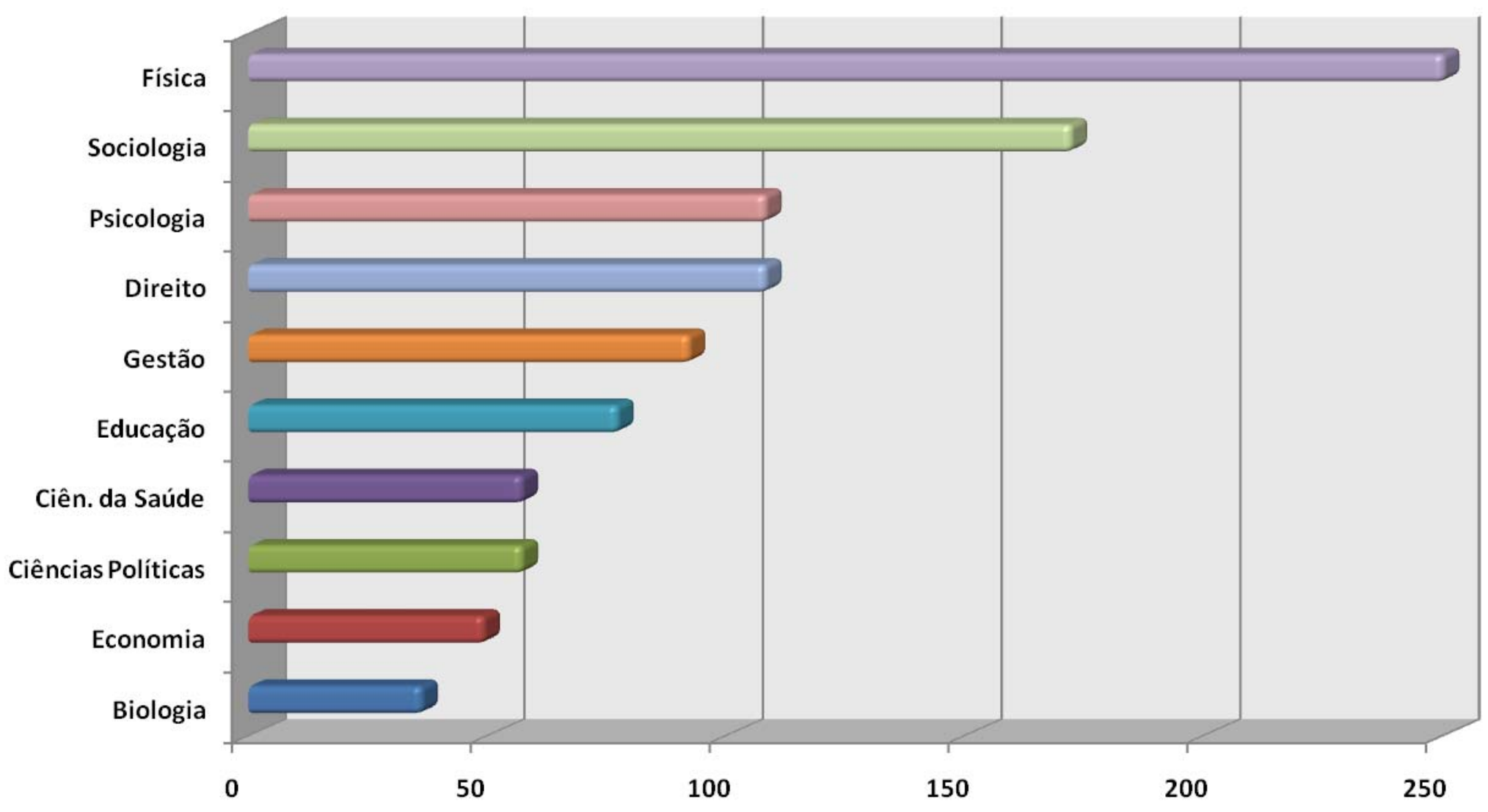




\section{Componentes da vantagem $\mathrm{OA}$}

$$
\mathrm{EA}+\mathrm{QA}+\mathrm{UA}+(\mathrm{CA})+(\mathrm{QB})
$$

EA: Early Advantage >> Vantagem da Antecipação

QA: Quality Advantage (seglen 80/20 effect) $>>$ Vantagem da Qualidade

UA: Usage Advantage \> Vantagem do Uso

(CA: Competitive Advantage) $\gg$ Vantagem Competitiva

(QB: Quality Bias) >> Propensão para a Qualidade 
Estudos sobre o impacto dos artigos em acesso livre

- Já existe uma bibliografia sobre este assunto: The effect of open access and downloads ('hits') on citation impact: a bibliography of studies

http://opcit.eprints.org/oacitation-biblio.html 
Duas vias para o Acesso Livre

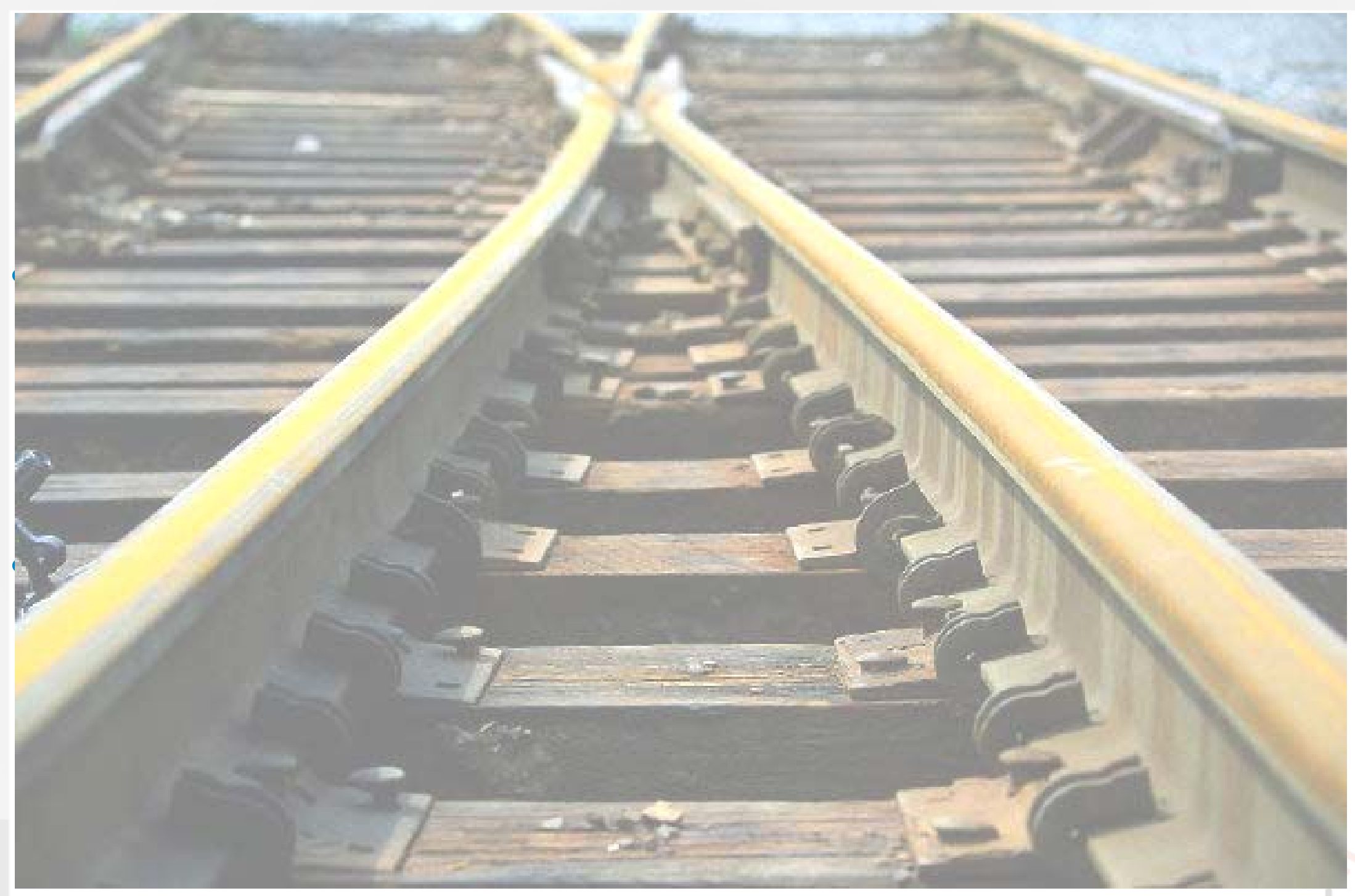

Universidade do Minho Serviços de Documentação 
O que são Repositórios Institucionais?

- São sistemas de informação que armazenam, preservam, divulgam e dão acesso à produção intelectual de comunidades universitárias. Ao fazê-lo intervêm em duas questões estratégicas:

- contribuir para o aumento da visibilidade e "valor" público das instituições, servindo como indicador tangível da sua qualidade;

- contribuir para a reforma do sistema de comunicação científica, expandindo 0 acesso aos resultados da investigação e reassumindo o controlo académico sobre a publicação científica. 


\section{Os Repositórios no mundo... $\%$ Rerenent}

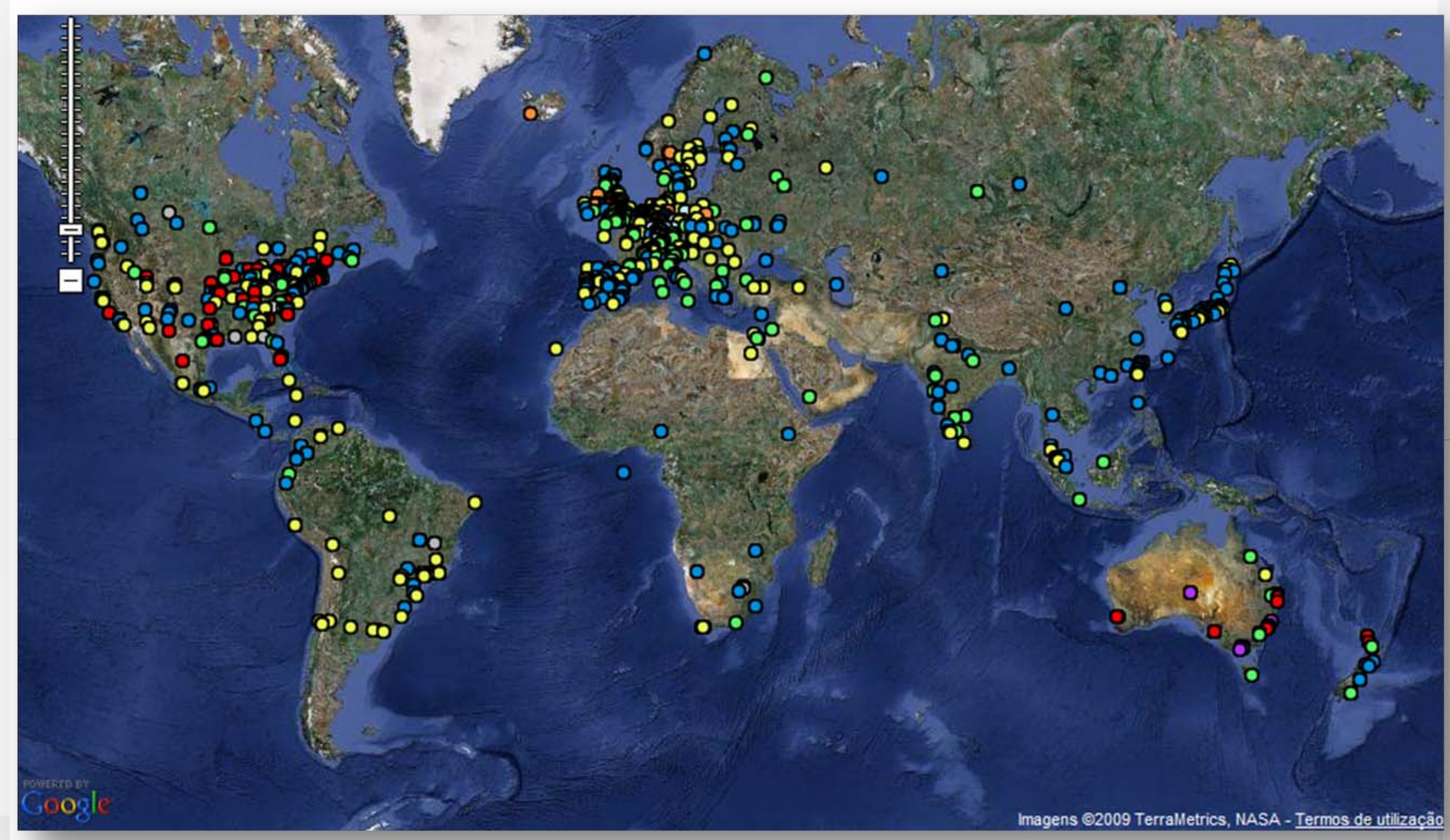




\section{Via verde para o auto-arquivo!}

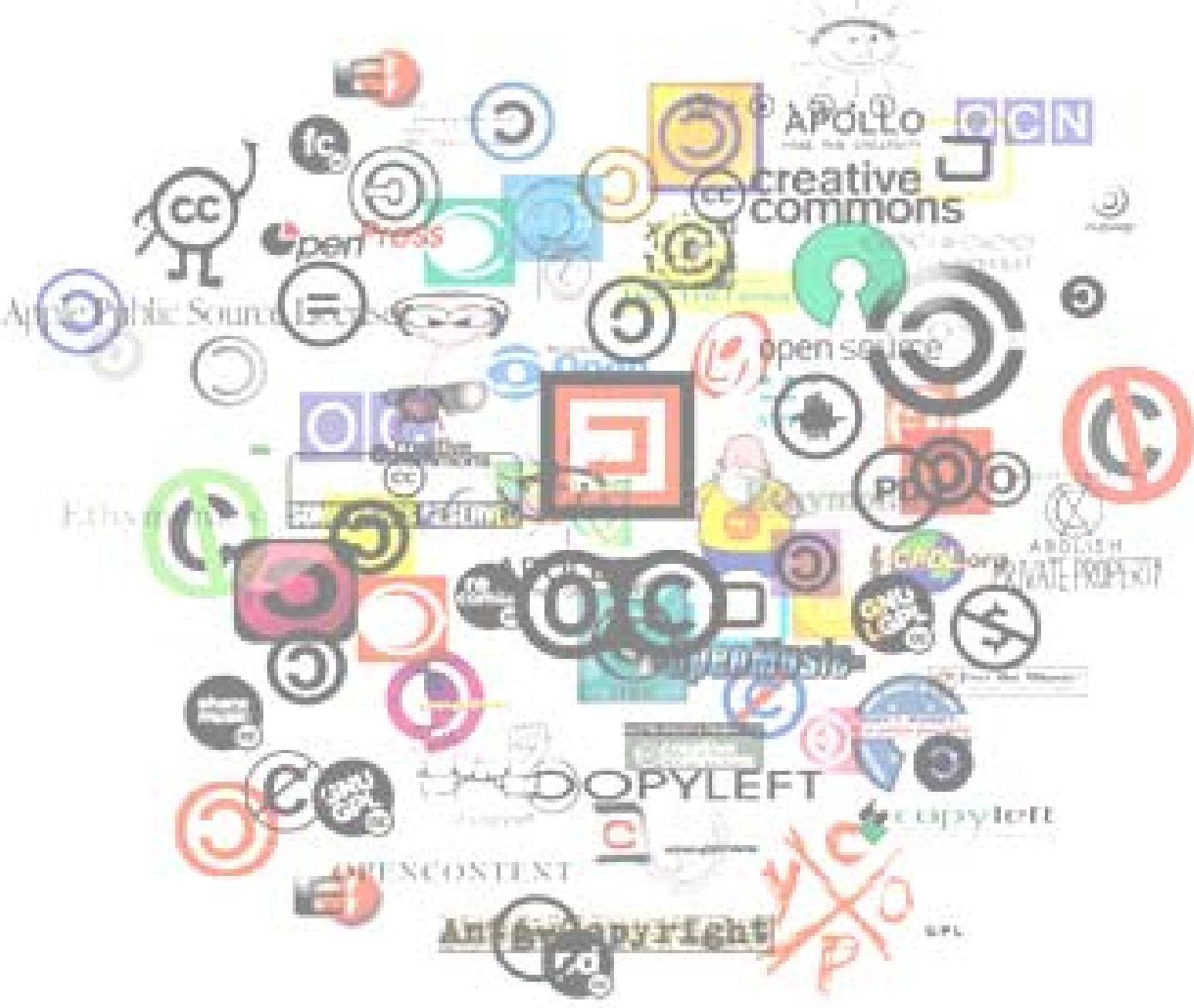


A evolução e afirmação do Acesso Livre 
Destaques de 2005...

\section{- 1 de Outubro de 2005}

\section{welloometrust}

Início da política de Open Access do Wellcome Trust, open-access

mandate, com impacto nas investigações que financia.

- Expects authors of research papers to maximise the opportunities to make their results available for free and, where possible, to retain their copyright.

- Will provide grantholders with additional funding to cover the costs of page processing charges levied by publishers who support the open access model.

- Requires electronic copies of any research papers that have been accepted for publication in a peer-reviewed journal, and are supported in whole or in part by Wellcome Trust funding, to be deposited into PubMed Central (or UK PubMed Central once established). Note that this requirement applies only to all grants awarded after 1 October 2005, and from 1 October 2006 to all grants regardless of award date.

- Affirms the principle that it is the intrinsic merit of the work, and not the title of the journal in which an author's work is published, that should be considered in making funding decisions and awarding grants. 
Destaques de 2006...

- 5 de Fevereiro de 2006

É apresentado no Senado dos Estados Unidos o

Research Public Access Act of 2006.

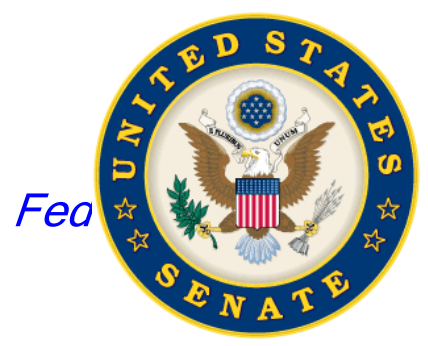

FRPAA will mandate $O A$ and limit embargoes to six months. It will apply to all federal funding agencies above a certain size --including the NIH, NSF, NASA, $E P A$, and eight Cabinet-level Departments. It instructs each agency to develop its own policy, under certain guidelines laid down in the bill. Some of those agencies might choose to launch central repositories but others might choose to mandate deposit (for example) in the author's institutional repository. But all must insure OA "as soon as practicable, but not later than 6 months after publication in peerreviewed journals". 


\section{Destaques de 2006...}

\section{- 31 de Março de 2006}

A União Europeia publica um estudo, Study on the economic and

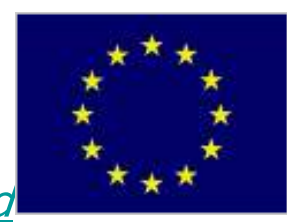

technical evolution of the scientific publication markets in Europe, sobre as

condições de acesso e difusão das publicações científicas.

"RECOMMENDATION A1. GUARANTEE PUBLIC ACCESS TO PUBLICLY-FUNDED RESEARCH RESULTS SHORTLY AFTER PUBLICATION. Research funding agencies have a central role in determining researchers' publishing practices. Following the lead of the NIH and other institutions, they should promote and support the archiving of publications in open repositories, after a (possibly domain-specific) time period to be discussed with publishers. This archiving could become a condition for funding. The following actions could be taken at the European level: (i) Establish a European policy mandating published articles arising from EC-funded research to be available after a given time period in open access archives, and (ii) Explore with Member States and with European research and academic associations whether and how such policies and open repositories could be implemented. ". 
Destaques de 2006...

- 27 e 28 de Novembro de 2006

$2^{\text {a }}$ Conferência sobre o Acesso Livre ao Conhecimento na Universidade do Minho - É apresentada uma Declaração do CRUP sobre o Open Access

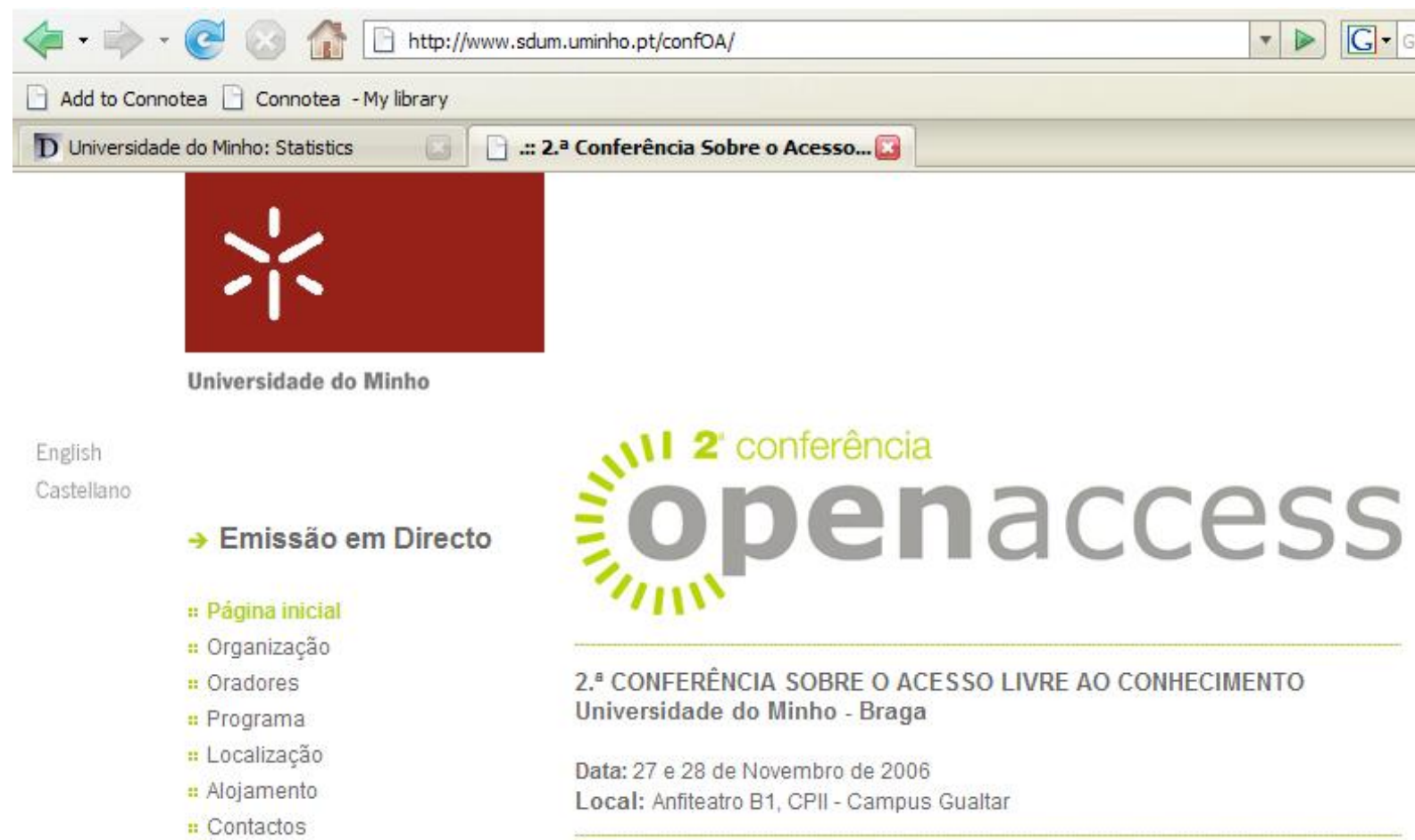




\section{Declaração do CRUP}

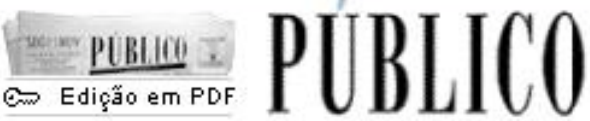

28 de Novembro de 2006 $10 \mathrm{~h} 36$

$\begin{array}{llll}\$ & \text { Lisbog } & \ldots \ldots \ldots . . . . & 6 \\ \star & \text { Porto } & \ldots \ldots \ldots \ldots . . & 3 \\ & \text { Faro } & \ldots \ldots \ldots \ldots . . . & 6\end{array}$

\begin{tabular}{l|l|l|l|l|l|l|l|l|l} 
10 & Canais & Colecções & Plus & Informações úteis & Assinaturas & Alertas Público & Público Digital
\end{tabular}

\section{PLUS}

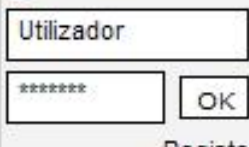

Registo

ED. IMPRESSA

Destaque

Espaço Público

Nacional

Mundo

Economia

Sociedade

Ciências

Desporto

Cultura

Media

Local Lisboa

Local Porto

Local Centro

Última Página

indice Geral

Edição para Cegos

SUPLEMENTOS

\section{PÚBLICO - EDIÇẤO IMPRESSA - CIÊNCIAS}

Director: José Manuel Fernandes

Directores-adjuntos: Nuno Pacheco e Manuel Carvalho

POL $n^{\circ} 6089$ | Terça, 28 de Novembro de 2006

\section{Reitores querem que a ciência publicada seja gratuita para} todos

David Marçal

Arquivos institucionais são importantes na disponibilização dos artigos cientificos

O Conselho de Reitores das Universidades Portuguesas (CRUP) apoia o acesso sem restrições às publicações cientificas. Uma declaração nesse sentido foi apresentada na segunda Conferência sobre o Acesso Livre ao Conhecimento, que encerra hoje, na Universidade do Minho.

Acesso livre à produção cientifica significa que tudo o que é publicado em revistas cientificas esteja disponivel na Internet para ser lido, descarregado, copiado, distribuido e usado como se queira. Este nem sempre é o caso, por exemplo, os conteúdos das prestigiadas publicações cientificas Science e Nature não estão disponiveis gratuitamente nos sites das revistas.

No entanto, existe um relevante movimento internacional de cientistas que quer

28 de Novembro de 2006 - 10 h36

$\mathbf{Y}$

SUPLEMENTO

GADJETO

DILO

BLOG
BEATLES

Ouça aqui 4 canções de LOVE

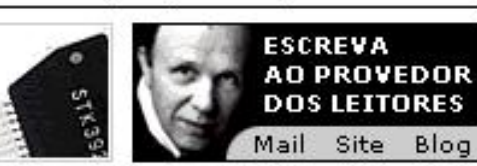

ARTE

PHOTOGRAPHICA

BLOG

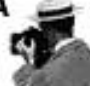

PESP

-CMEDIDA

OBESIDADE

NUTRIÇĀO

actividade

FísICA

MEDIA

BLOG

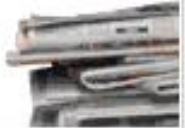

TIMOR

LESTE

BLOG

Um Poema Por Semana

QDuruidas OLingursticas as

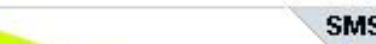




\section{Destaques de 2007}

\section{- 15 e 16 de Fevereiro de 2007}

Conferência Scientific Publishing in the European Research Area Access, Dissemination and Preservation in the Digital Age, promovida pela Comissão Europeia, na sequência do estudo Study on the economic and technical evolution of the scientific publication markets in Europe.

No início da conferência foi entregue uma petição apoiando a recomendação do estudo europeu de estabelecer uma política que exija o acesso livre aos resultados de investigação financiada com fundos públicos. A petição tinha reunido cerca de 18.000 assinaturas individuais e mais de 500 assinaturas institucionais (entre as quais as de dois Reitores portugueses e do Presidente do CRUP).

A Declaração Final da Conferência não define uma verdadeira política, mas apenas a continuação de iniciativas, estudos e experiências. 
A entrega da petição $\mathrm{OA}$

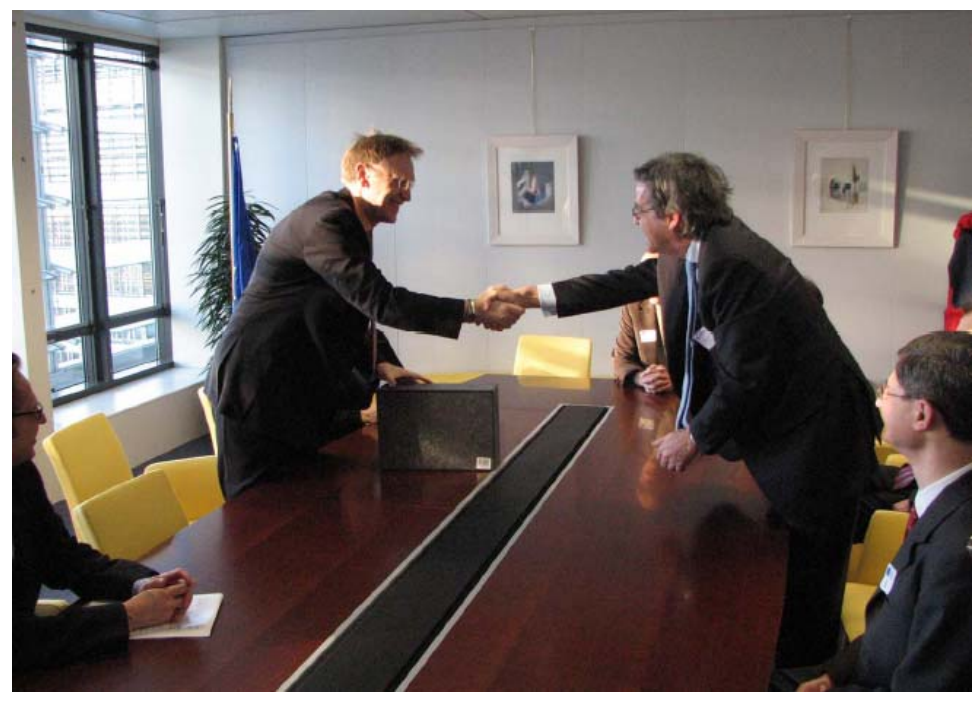

O Comissário Europeu para a Ciência \& Investigação, Jan Potocnik, recebeu a petição antes da conferência.

Foi entregue pelo Dr. Sijbolt Noorda da European Universities Association (EUA), uma instituição que representa 780 universidades na Europa

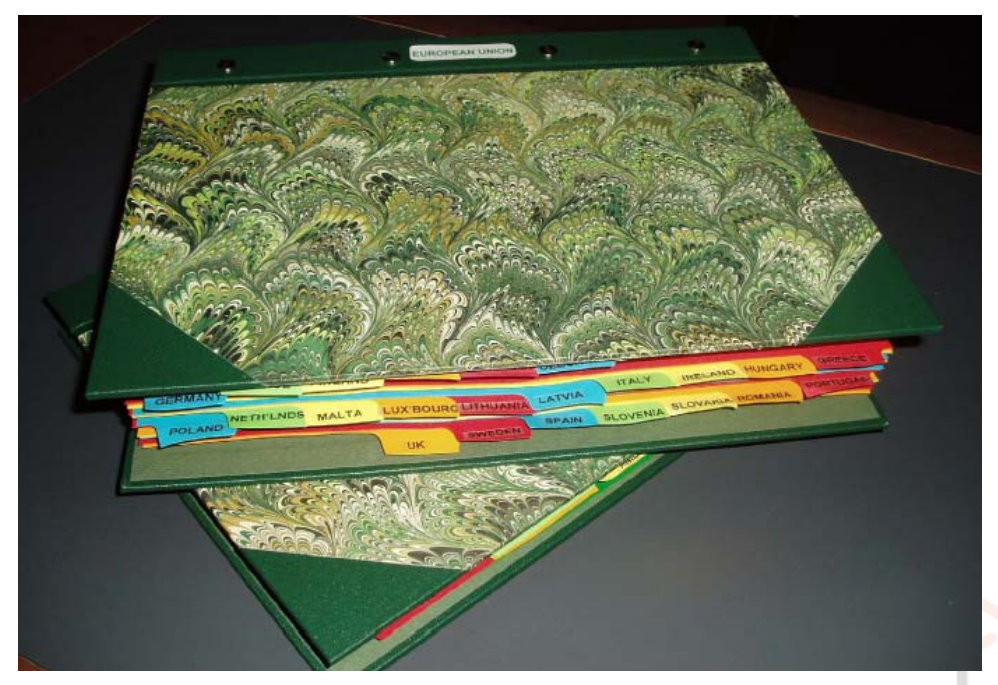


- 6 de Setembro de 2007

O Arts \& Humanities Research Council (AHRC), membro do RCUK, divulga a sua Open Access policy.

Depois deste anúncio do AHRC, dos 8 Research Councils UK, 6 já definiram OA mandates: AHRC, BBSRC, ESRC, MRC, NERC, y PPARC. O CCLRC optou por um simples encorajamento e o outro (EPSRC) ainda está em deliberação.

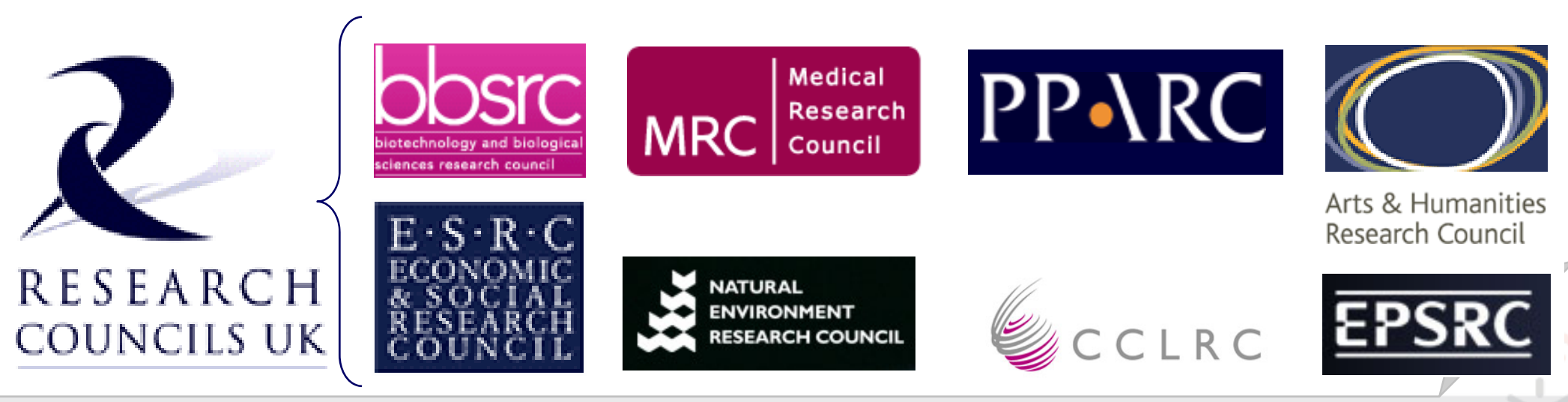


Destaques de 2007

The Scientific Council

of the European Research Council

Scientific Council of the European Research Council define uma política obrigatória de auto-arquivo em acesso livre.

(...)

The ERC requires that all peer-reviewed publications from ERCfunded research projects be deposited on publication into an appropriate research repository where available, such as PubMed Central, ArXiv or an institutional repository, and subsequently made Open Access within 6 months of publication. 


\section{Destaques de 2008...}

- 11 de Janeiro de 2008

U.S.Department of Health \& Human Services

A política de auto-arquivo do NIH (EUA), até à altura voluntária, passa a obrigatória.

In accordance with Division G, Title II, Section 218 of PL 110-161 (Consolidated Appropriations Act, 2008

), the NIH voluntary Public Access Policy (NOT-OD-05-022) is now mandatory. The law states:

The Director of the National Institutes of Health shall require that all investigators funded by the NIH submit or have submitted for them to the National Library of Medicine PubMed Central an electronic version of their final, peer-reviewed manuscripts upon acceptance for publication, to be made publicly available no later than 12 months after the official date of publication: Provided, That the NIH shall implement the public access policy in a manner consistent with copyright law. 
- 12 de Fevereiro de 2008

A Faculdade de Artes Ciências da Universidade de Harvard estabelece uma política sobre as publicações científicas dos seus membros, que requer, para além do depósito dos artigos, a transferência do copyright para a Universidade.

Each Faculty member grants to the President and Fellows of Harvard College permission to make available his or her scholarly articles and to exercise the copyright in those articles. In legal terms, the permission granted by each Faculty member is a nonexclusive, irrevocable, paid-up, worldwide license to exercise any and all rights under copyright relating to each of his or her scholarly articles (...). The policy will apply to all scholarly articles written while the person is a member of the Faculty (...).

- 7 de Maio de 2008

\section{HARVARD LAW SCHOOL}

A Harvard Law School estabelece uma política sobre as publicações científicas dos seus membros semelhante à da Faculdade de Artes e Ciências da Universidade de Harvard. 


\section{Destaques de 2008...}

- 26 de Março de 2008

O Conselho Geral da European University Association (EUA) aprovou por unanimidade as recomendações do Grupo de Trabalho sobre Open Access da EUA.

\section{A. Recommendations for University Leadership}

1. (...) develop institutional policies and strategies that foster the availability of (...) research results (...), maximising their visibility, accessibility and scientific impact.

2. The basic approach for achieving this should be the creation of an institutional repository or participation in a shared repository. (...)

3. University institutional policies should require that their researchers deposit (self-archive) their scientific publications in their institutional repository upon acceptance for publication. (...).Such policies would be in compliance with evolving policies of research funding agencies at the national and European level such as the ERC.

4. University policies should include copyright in the institutional intellectual property rights (IPR) management (...). 


\section{Destaques de 2008...}

- 10 de Junho de 2008

\section{Política de auto-arquivo da Stanford University School of Education}

(...)

Faculty members grant to the Stanford University permission to make publicly available their scholarly articles and to exercise the copyright in those articles. They grant to Stanford University a nonexclusive, irrevocable, worldwide license to exercise any and all rights under copyright relating to their scholarly articles, in any medium (...).

The policy will apply to all scholarly articles authored or co-authored while a faculty member of the School of Education, beginning with articles for which the publisher's copyright agreement has yet to be signed.

(...)

No later than the date of publication, faculty members will provide an electronic copy of the final version of the article at no charge to the appropriate representative of the Dean of Education's Office, who will make the article available to the public in an open-access repository operated by Stanford University (...) 


\section{Destaques de 2008...}

- 20 de Agosto de 2008

Projecto piloto de Comissão Europeia para assegurar a máxima disseminação e visibilidade dos resultados da investigação financiada pelo 7th Framework Programm ( 50 biliões de $€$ ). O projecto vai abarcar cerca de $20 \%$ do 7 th FP ( 10 biliões de $€)$ em disciplinas como ciências da saúde, energia, ambiente, ciências sociais e tecnologias de informação e comunicação.

"Grant recipients will be required to deposit peer reviewed research articles or final manuscripts resulting from their FP7 projects in an online repository. They will have to make their best effort to ensure open access to these articles within either six or twe/ve months after publication, depending on the research area." 
18 de Março de 2009

\section{Mandato de Open Access para todo o MIT, aprovado por unanimidade}

The Faculty of the Massachusetts Institute of Technology is committed to disseminating the fruits of its research and scholarship as widely as possible. In keeping with that commitment, the Faculty adopts the following policy: Each Faculty member grants to the Massachusetts Institute of Technology nonexclusive permission to make available his or her scholarly articles and to exercise the copyright in those articles for the purpose of open dissemination. In legal terms, each Faculty member grants to MIT a nonexclusive, irrevocable, paid-up, worldwide license to exercise any and all rights under copyright relating to each of his or her scholarly articles, in any medium, provided that the articles are not sold for a profit, and to authorize others to do the same. The policy will apply to all scholarly articles written while the person is a member of the Faculty except for any articles completed before the adoption of this policy and any articles for which the Faculty member entered into an incompatible licensing or assignment agreement before the adoption of this policy. The Provost or Provost's designate will waive application of the policy for a particular article upon written notification by the author, who informs MIT of the reason.

To assist the Institute in distributing the scholarly articles, as of the date of publication, each Faculty member will make available an electronic copy of his or her final version of the article at no charge to a designated representative of the Provost's Office in appropriate formats (such as PDF) specified by the Provost's Office.

The Provost's Office will make the scholarly article available to the public in an open- access repository. (...) 


\section{Novos mandatos (desde Maio)}

- University of Bergen

- Faculty in the Harvard Graduate School of Education

- University College London

- University of Geneva

- University of Kansas

- Hungarian Scientific Research Fund (Országos Tudományos Kutatási Alapprogramok, or OATKA )

- University of Westminster

- University of Leicester

- Copenhagen Business School

- University of Tampere ("quase mandato") 
A Experiência da Universidade do Minho 


\section{Origem da iniciativa}

- Constituição de um repositório institucional foi definido como objectivo estratégico dos Serviços de Documentação da Universidade do Minho (SDUM) em 2003

- Repositório institucional integrou a candidatura da Universidade do Minho (UM) ao Programa E-U Campus Virtual 
A experiência da Universidade do Minho

- Criação do RepositóriUM - Repositório Institucional da Universidade do Minho em 2003.

- Definição de uma política institucional de auto-arquivo, em vigor desde Janeiro de 2005. 


\section{O que é o RepositóriUM?}

- É o repositório institucional da Universidade do Minho.

- É um sistema de informação que armazena, preserva, divulga e dá acesso à produção intelectual da U.M. em formato digital. 
Criação e desenvolvimento do RepositóriUM

- Objectivos do RepositóriUM:

- Contribuir para aumentar o impacto da investigação desenvolvida na Universidade do Minho, aumentando a sua visibilidade e acessibilidade;

- Preservar a memória intelectual da Universidade do Minho;

- Facilitar a gestão da informação na Universidade 


\section{Quais são as grandes linhas de orientação?}

- O RepositóriUM está organizado em comunidades

- As comunidades correspondem a unidades orgânicas (Departamentos, Centros de Investigação, etc.) da U.M.

- Cada comunidade pode criar várias colecções 


\section{Que tipo de documentos podem ser}

\section{integrados?}

- Algumas orientações gerais relacionadas com os conteúdos que podem ser integrados no RepositóriUM:

- Ser produzido (autor ou co-autor) por membro(s) da U.M.;

- Resultar de actividades de I\&D ou ensino;

- Não ser efémero;

- Estar em formato digital;

- Estar completo e pronto para "publicação";

- O autor deve poder, e estar disposto a, conceder à U.M. o direito não-exclusivo de preservar e dar acesso ao seu trabalho através do RepositóriUM. 
Implementação do RepositóriUM

- Iniciada em Maio de 2003. Quatro fases:

- 1a Fase - Instalação, Configuração, Tradução e Formação

- Instalação da infra-estrutura física e lógica.

- Análise mais aprofundada de todas as funcionalidades e configuração.

- Desenvolvimento da interface gráfica.

- Personalização e tradução da interface para a língua portuguesa.

- Formação interna. 


\section{Implementação do RepositóriUM}

- 2a Fase - Carregamento de Teses e Dissertações

- Foi definida como a área prioritária para o início do carregamento de conteúdos no sistema.

- Foram disponibilizadas várias vias para que os autores entregassem os seus documentos: Correio electrónico, FTP, entrega directa.

- Foi ainda disponibilizado o serviço de digitalização para documentos não disponíveis em formato digital.

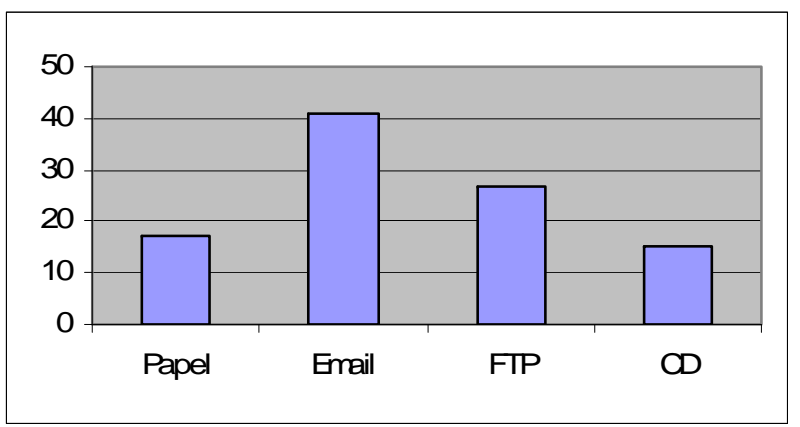




\section{Implementação do RepositóriUM}

- 3a Fase - Constituição de Comunidades Piloto

- Com o objectivo de testar a utilização do sistema com outros tipos de documentos, para além de teses e dissertações, e com utilizadores externos aos Serviços de Documentação.

- Foram endereçados convites a 6 unidades orgânicas da UM, seleccionadas com base em diversos critérios. Das 6 unidades contactadas 4 acederam de imediato ao convite.

- Cada comunidade definiu as suas colecções, os processos de depósito e de aceitação e políticas de acesso. 


\section{Implementação do RepositóriUM}

\section{- 4a Fase - Abertura ao Público}

- Abertura oficial no dia 20 de Nov. de 2003, numa cerimónia presidida pelo Reitor da

Universidade do Minho.

- O RepositóriUM abriu com um total de 280 documentos.

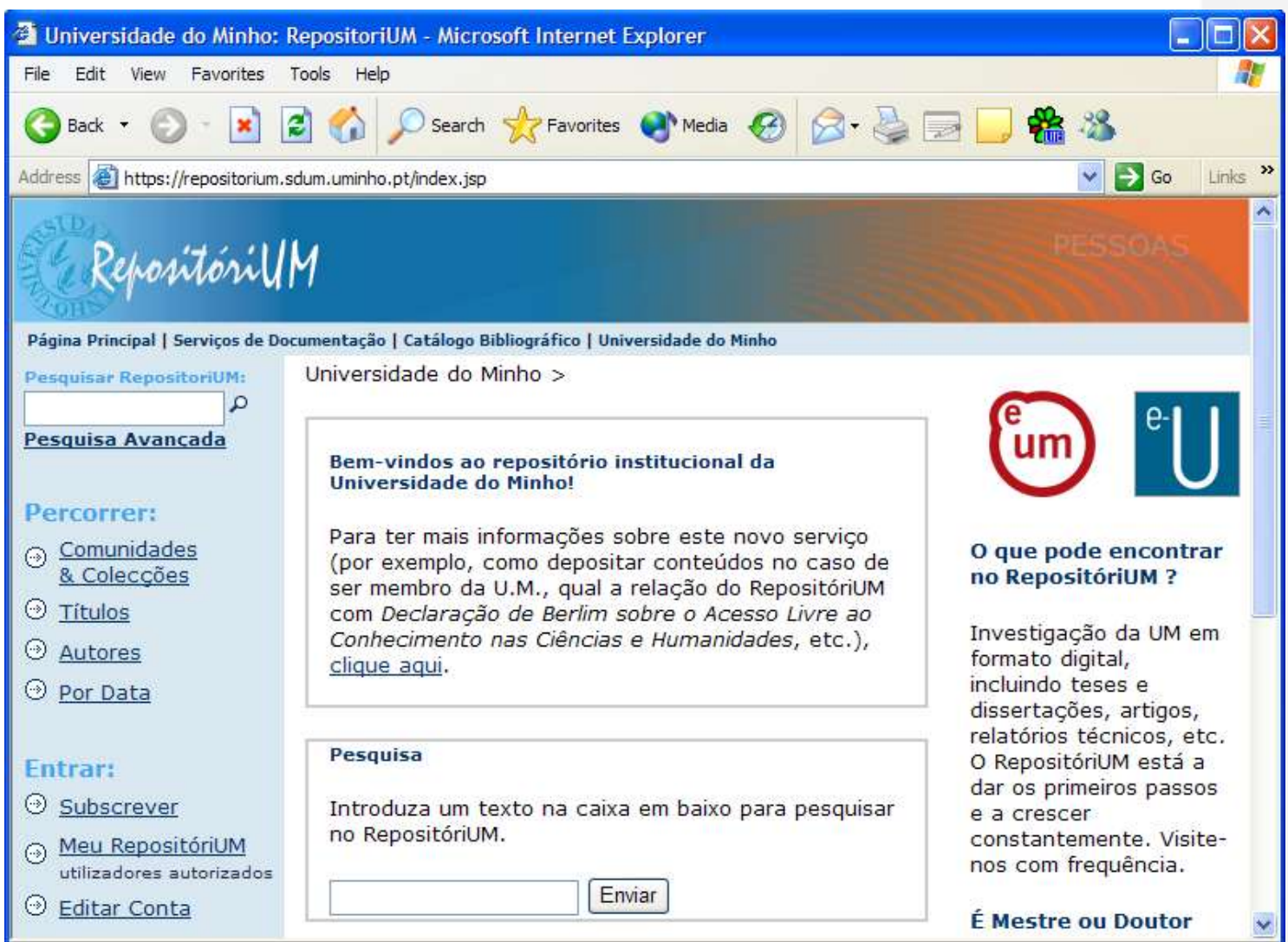


A evolução do RepositóriUM em 2004

- Primeiro semestre de 2004

- Contacto escrito com todas as unidades da U.M.

- Apresentação do RepositóriUM a 10 unidades

(Departamentos/Escolas) da U.M.

- 2 novas comunidades constituídas

- 3 das comunidades piloto paralisaram o depósito de documentos 


\section{A evolução do RepositóriUM em 2004}

- Conclusão

- O número de documentos

- O número de comunidades

- Evoluíu mais lentamente do que o previsto e desejável

- Principal dificuldade - o depósito de conteúdos (auto-arquivo) pelos autores:

- Dúvidas e dificuldades relacionadas com a propriedade intelectual e direitos de autor (copyright) das publicações;

- Procedimentos de trabalho, hábitos, valores, expectativas e receios diversos em diferentes comunidades científicas;

- Inércia ou sobrecarga de trabalho dos autores;

- Dificuldades e barreiras tecnológicas 


\section{A estratégia definida}

- Estratégia de comunicação e promoção no interior e exterior da Universidade

- Participação activa na comunidade internacional relacionada com o Open Access, os Repositórios Insitucionais e o DSpace

- Desenvolvimento de serviços de valor acrescentado para os autores

- Definição de uma política institucional da Universidade 


\section{Comunicação e promoção}

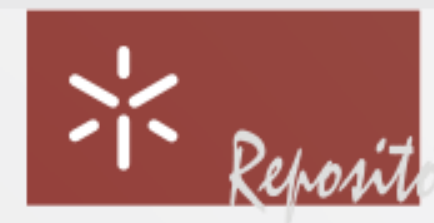

- 26 apresentações na U.M., entrevistas e notícias nas publicações da Universidade, materiais promocionais, Websites da U.M., etc.

- Cerca de 20 papers, apresentações e palestras em conferências, seminários e workshops nacionais e internacionais (Alemanha, Brasil, Espanha, Norueg Reino Unido ).

- Organização das Conferênciaa sobre o Acesso Li' em Portugal (2005, 2006, 2008)
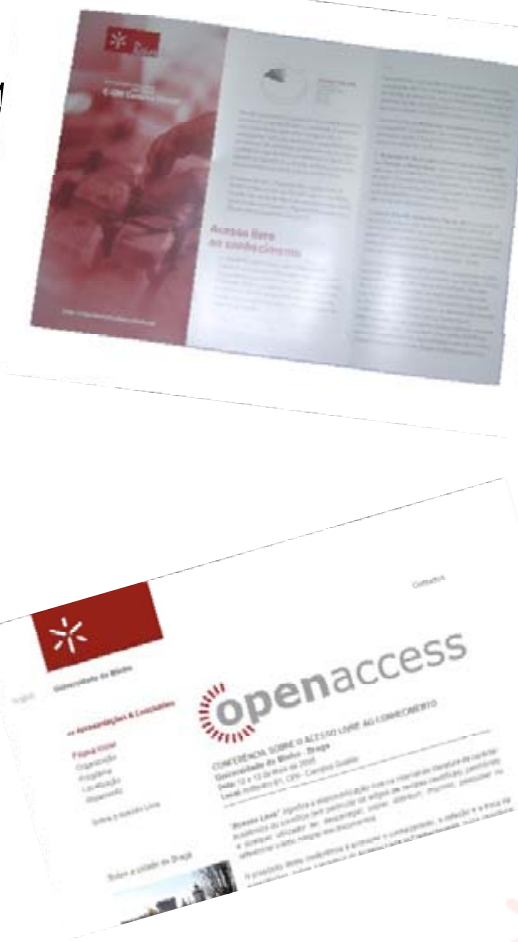


\section{Participação activa nas comunidades OA}

\section{e DSpace}

- Participação no projecto Google-DSpace

- Participação em reuniões, workshops, etc.

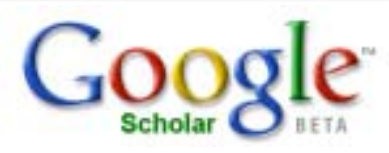

- Implementing the benefits of OAI (OAI3), CERN, Geneva, 2004

- DSpace User Group Meeting, MIT, Boston, 2004

- Berlin 3: Open Access, Southampton, 2005

- JISC International Colloquium, London, 2005

- DSpace User Group Meeting, Cambridge, 2005

- DSpace User Group Meeting, Bergen, 2006

- Dspace User Group Meeting, Roma, 2007

- Desenvolvimento de Add-ons ao DSpace

- Sugerir a um colega (já no código da versão 1.4)

- Ontologias (já no código da versão 1.4)

- Solicitar cópia ao autor (request a copy add-on)

- Estatísticas

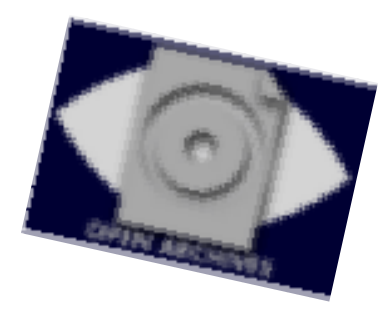

- Comentário, teia de comunicação, etc. 


\section{Serviços para os autores}

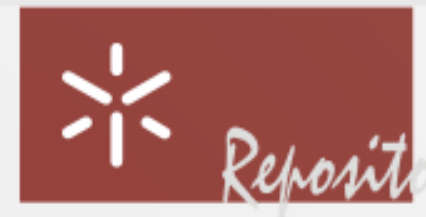

- Serviço de apoio e esclarecimento das questões relacionadas com os direitos de autor (copyright) dos seus artigos;

- Melhor informação de suporte aos utilizadores do RepositóriUM, através de guias, ajudas contextuais, etc.;

- Simplificação e melhoria da "usabilidade" da interface do processo de depósito;

- Estatísticas e relatórios de acessos e downloads de documentos;

- Interligação com o sistema de gestão de currículos/investigação (CRIS): DeGóis; 


\section{A Política de Auto-Arquivo}

de publicações na UM 
A política de Auto-Arquivo de publicações da U.M.

- Foi definida no primeiro aniversário do RepositóriUM, na sequência da assinatura, pelo Reitor, da Declaração de Berlim sobre o Acesso Livre ao Conhecimento, em 26 de Novembro de 2004, após consulta ao Conselho de Escolas.

- A política entrou em vigor em Janeiro de 2005 


\section{Princípios da política Auto-Arquivo de publicações}

\section{da U.M.}

- Os docentes e investigadores da Universidade do Minho que sejam autores ou coautores devem depositar as suas publicações e documentos no RepositóriUM Repositório Institucional da Universidade do Minho, para disponibilização em acesso livre, com as excepções definidas;

- As unidades orgânicas (centros de investigação e departamentos) devem subscrever e adoptar políticas de auto-arquivo/depósito da produção científica;

- Os autores de teses e dissertações aprovadas pela Universidade do Minho deverão autorizar o depósito da sua tese e dissertação no RepositóriUM. 


\section{Aplicação da política}

\section{- Incentivo}

- No ano de 2005, foi atribuído um financiamento adicional às Unidades Orgânicas, em função do número, e do tipo, de documentos depositados pelos seus membros no RepositóriUM e da definição de uma política de auto-arquivo da unidade.

- Em 2006 existiu também um incentivo, mas o seu valor foi significativamente inferior (cerca de $1 / 3$ ). 


\section{Os resultados...}

\begin{tabular}{|c|c|c|c|c|c|c|}
\hline & Dezembro 2004 & Dezembro 2005 & $\begin{array}{c}\text { Dezembro } \\
2006\end{array}$ & $\begin{array}{l}\text { Dezembro } \\
2007\end{array}$ & $\begin{array}{c}\text { Dezembro } \\
2008\end{array}$ & $\begin{array}{c}\text { Outubro } \\
2009\end{array}$ \\
\hline N.. de comunidades & 7 & 33 & 35 & 35 & 36 & 36 \\
\hline NN. de documentos & 626 & 3105 & 4990 & 6296 & 7391 & 8535 \\
\hline $\begin{array}{l}\text { N. de utilizadores } \\
\text { registados }\end{array}$ & 717 & 2410 & 3390 & 4301 & 5375 & 6281 \\
\hline
\end{tabular}


Tipos de Documentos no RepositóriUM
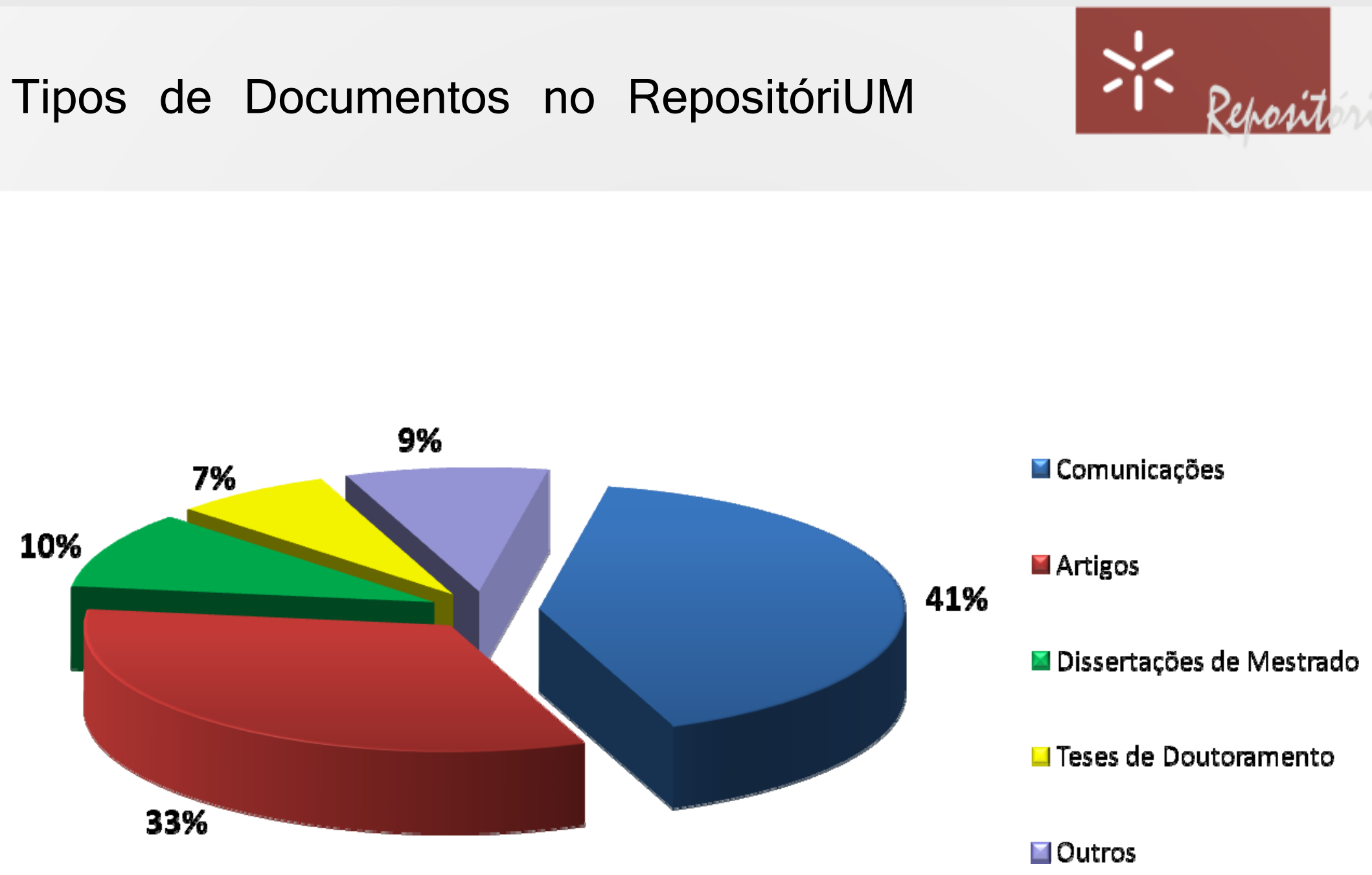
Documentos por tipo de acesso
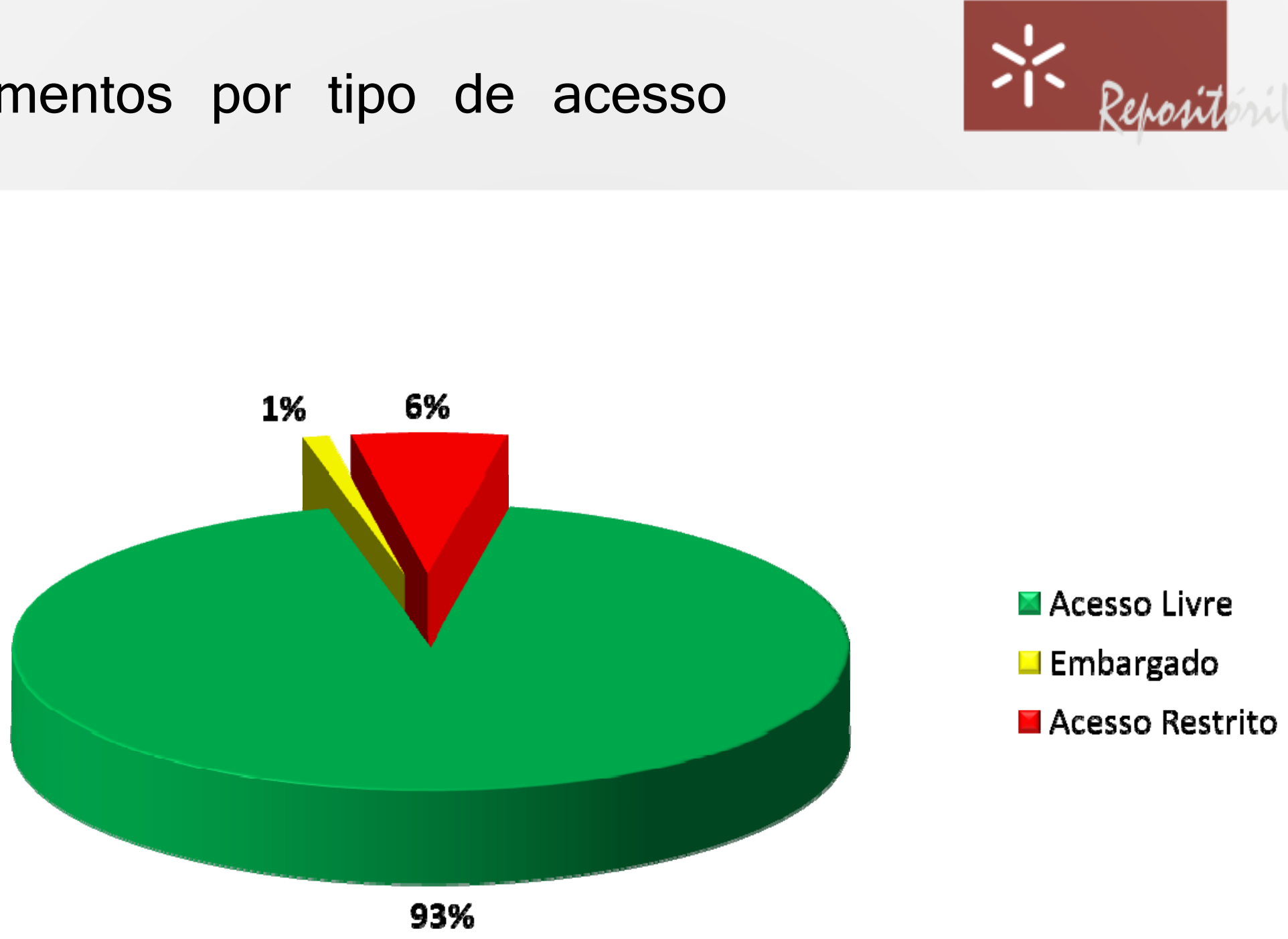
Número de visitantes/visitas até Outubro de 2009

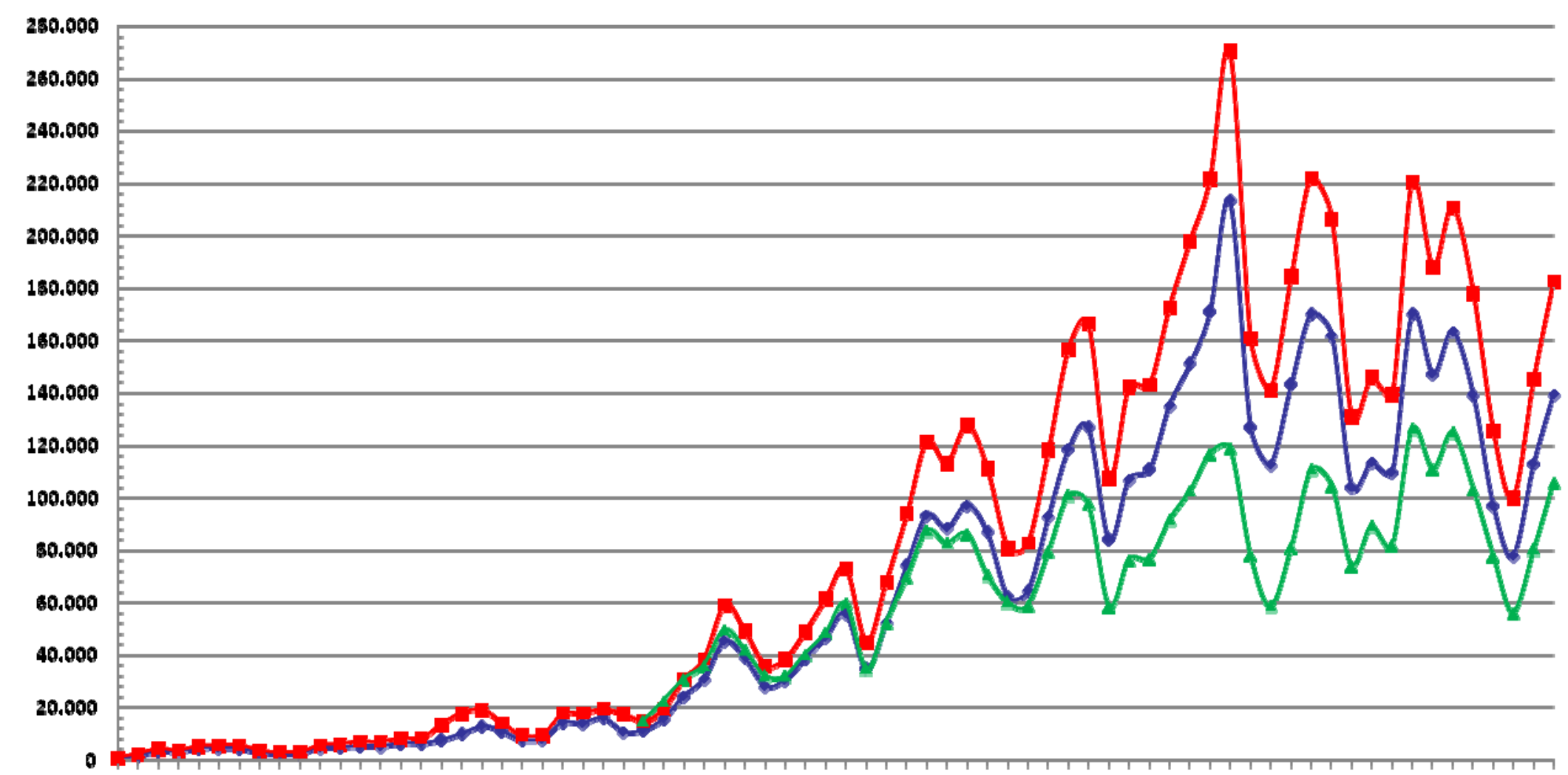
8000 20,

$\rightarrow$ Visitantes $\rightarrow$-Visitas $\rightarrow$ Downloads 
Origens dos downloads desde 2006

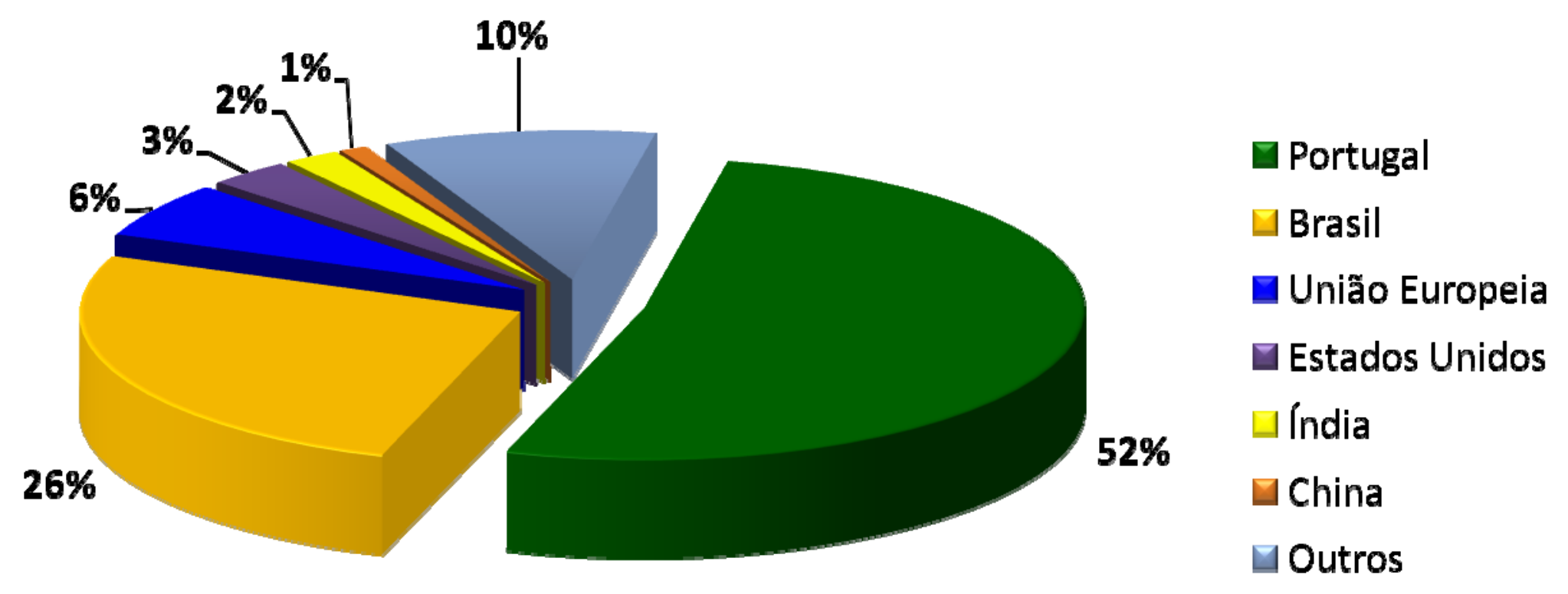




\section{Algumas lições da nossa experiência}

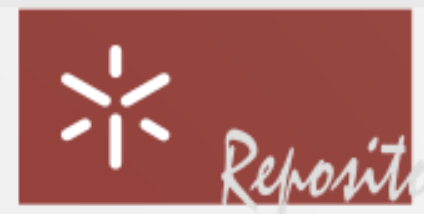

- Uma estratégia de divulgação, promoção e formação é um factor crítico para o sucesso na implementação de um RI, uma vez que é imprescindível para alterar alguns aspectos sociais e culturais que podem originar um fraco envolvimento por parte dos académicos.

- A criação de serviços de valor acrescentado para os autores, que compensem o esforço de auto-arquivo, é também um aspecto importante.

- Mas o factor determinante foi o estabelecimento de uma política que encorajou/tornou obrigatório o depósito da produção científica dos membros da U.M. no RepositóriUM. 
O que o ganhou a U.M. com a sua política

- Maior visibilidade e impacto para a sua produção científica e para a Universidade como um todo

- Reconhecimento na comunidade nacional e internacional do Open Access e dos repositórios que se traduziu, entre muitas outras coisas, em oportunidades para participar em projectos europeus e para coordenar técnica e cientificamente o projecto RCAAP 


\section{Vantagem Competitiva}

As universidades portuguesas no Ranking Web of World Universities (Julho 2009)

http://www.webometrics.info/rank_by_country.asp? country=pt

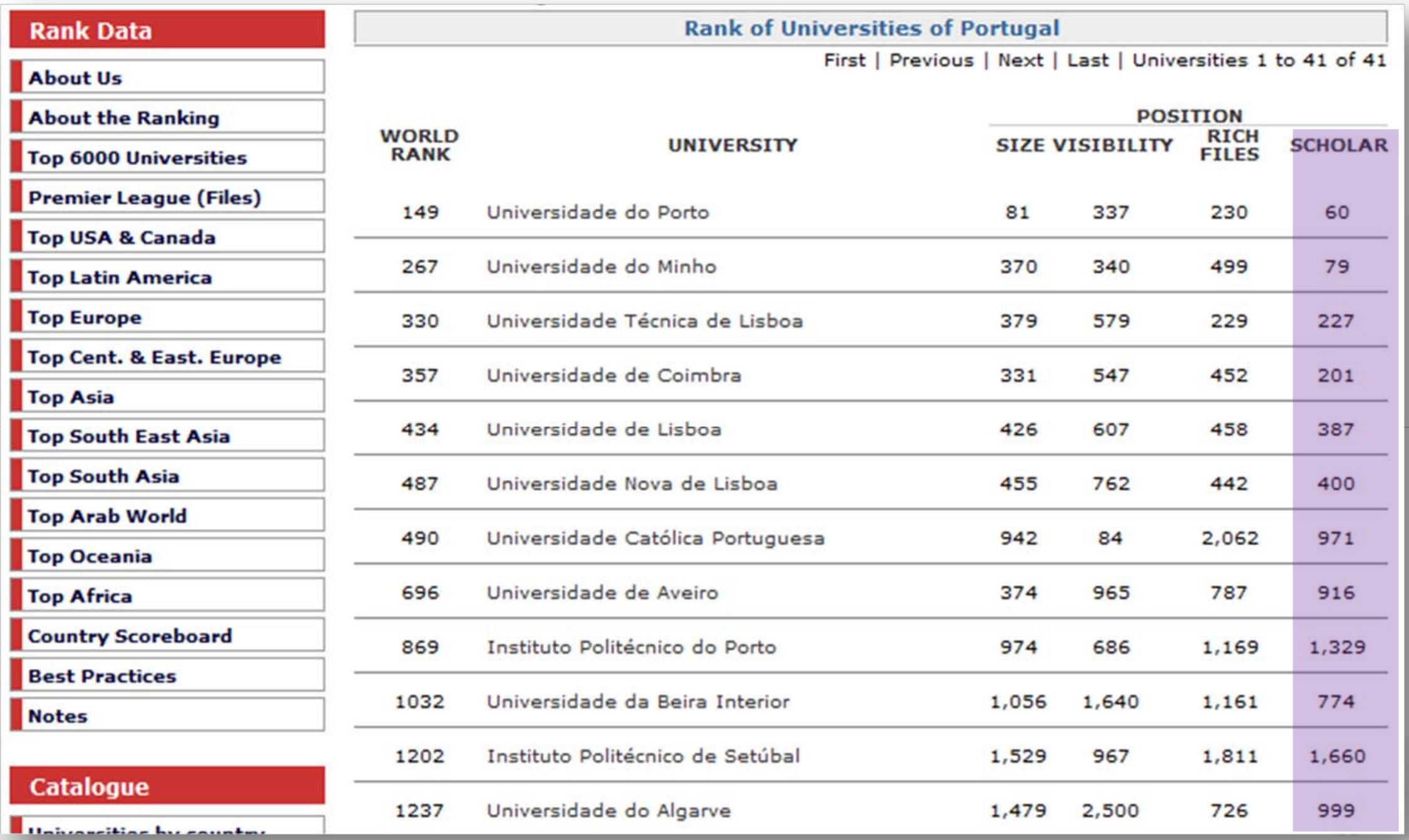

Universidade do Minho Serviços de Documentação 


\section{Projectos Europeus}

- DRIVER

- NECOBELAC

- OpenAIRE

- ... 


\section{DRIVER - Digital Repositories Infrastructure Vision for European Research}

\section{Projecto DRIVER II - Informação geral}

Duração: 24 meses

Orçamento: $2.7 \mathrm{~m}$ EUR

Calendário: 12/2007-11/2009

Principais Resultados:

$\checkmark$ Digital Repository Infrastructure

$\square$ European Digital Repository Confederation

Parceiros dos Consórcio

$\square$ Univ.of Athens (GR)

$\square$ Univ. of Bielefeld (GE)

CNR-ISTI (IT)

口 STICHTING SURF ( NL )

$\square$ Univ. of Nottingham (UK) cont...

Univ. of Bath (UK)

$\square$ Univ. of Warszawski (PO)

$\square$ Univ. of Gent (BE)

口 Univ. of Goettingen (GE)

$\square$ Danish Technical University (DK)

口 Universidade do Minho (PT)

$\square$ Narodna in univerzitetna knijznica ( SLO ) 
História do DRIVER

- DRIVER - (I), começou em Junho de 2006 e terminou em Novembro de 2007

- DRIVER II, começou em 1 de Dezembro de 2007, termina em 30 de Novembro de 2009 
Áreas e actividades do projecto DRIVER ॥

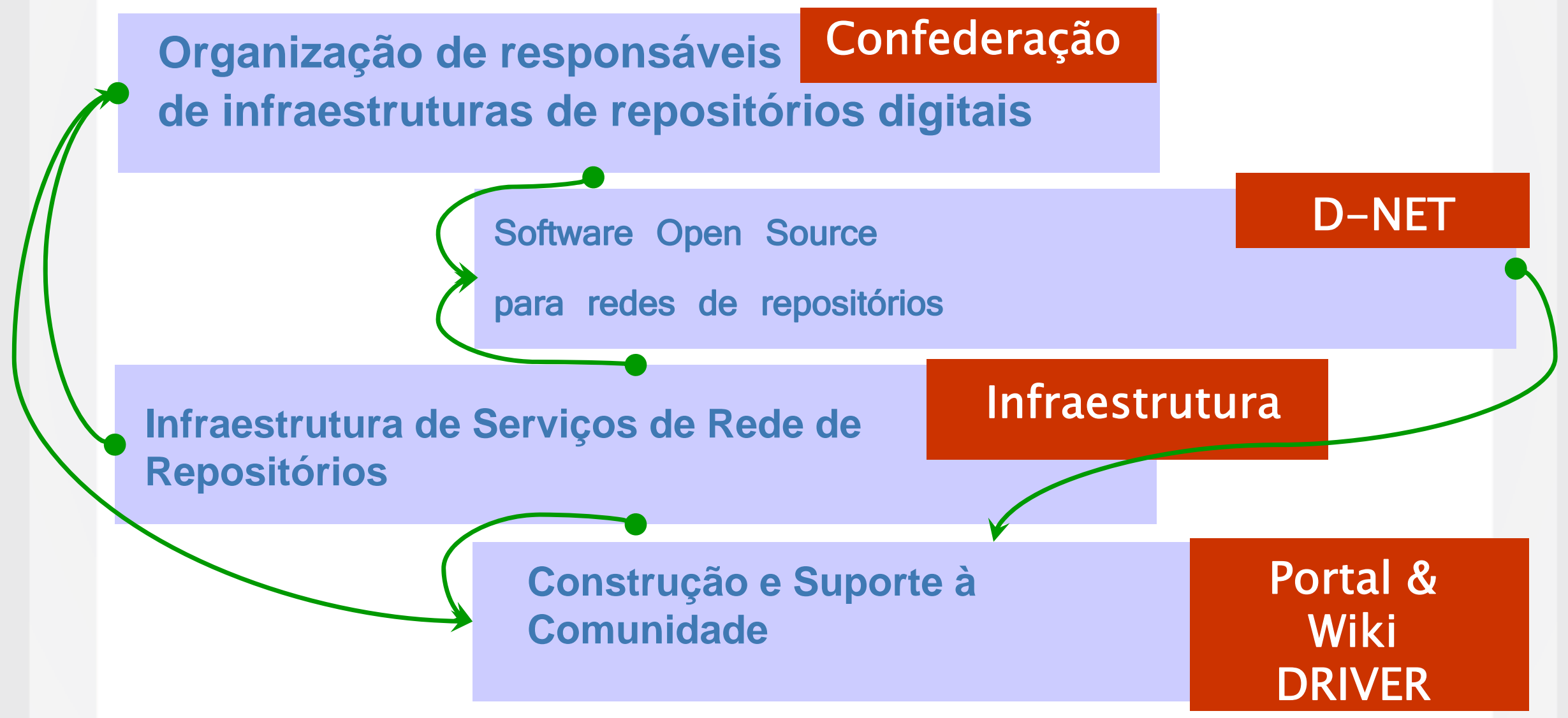




\section{D-NET Software: DRIVER Network-Evolution-Toolkit}

Versão 1.0 disponibilizada ao público em 20 de Junho de 2008 com uma licença Open Source Apache License

O software da infra-estrutura DRIVER inclui:

- Software de administração de redes de repositórios (como o Repository Network Manager, Resource Monitoring)

- Serviços para utilizadores finais (Search, Browse, Profiling)

- Serviço de suporte para repositórios locais e agregadores (Validation Tool) Versão 1.1 testada. Versão 2.0 em breve. 
A primeira implementação em operação: "European Information Space", pode ser acedida online em: www.driver-community.eu

Apoia três grupos de utilizadores:

1. Gestores de repositórios

2. Fornecedores de serviços

3. Investigadores, leitores, público 


\section{DRIVER European Information Space}

$250+$

repositórios

agregados

29

países

$1.000 .000+$

documentos

$25+$

idiomas

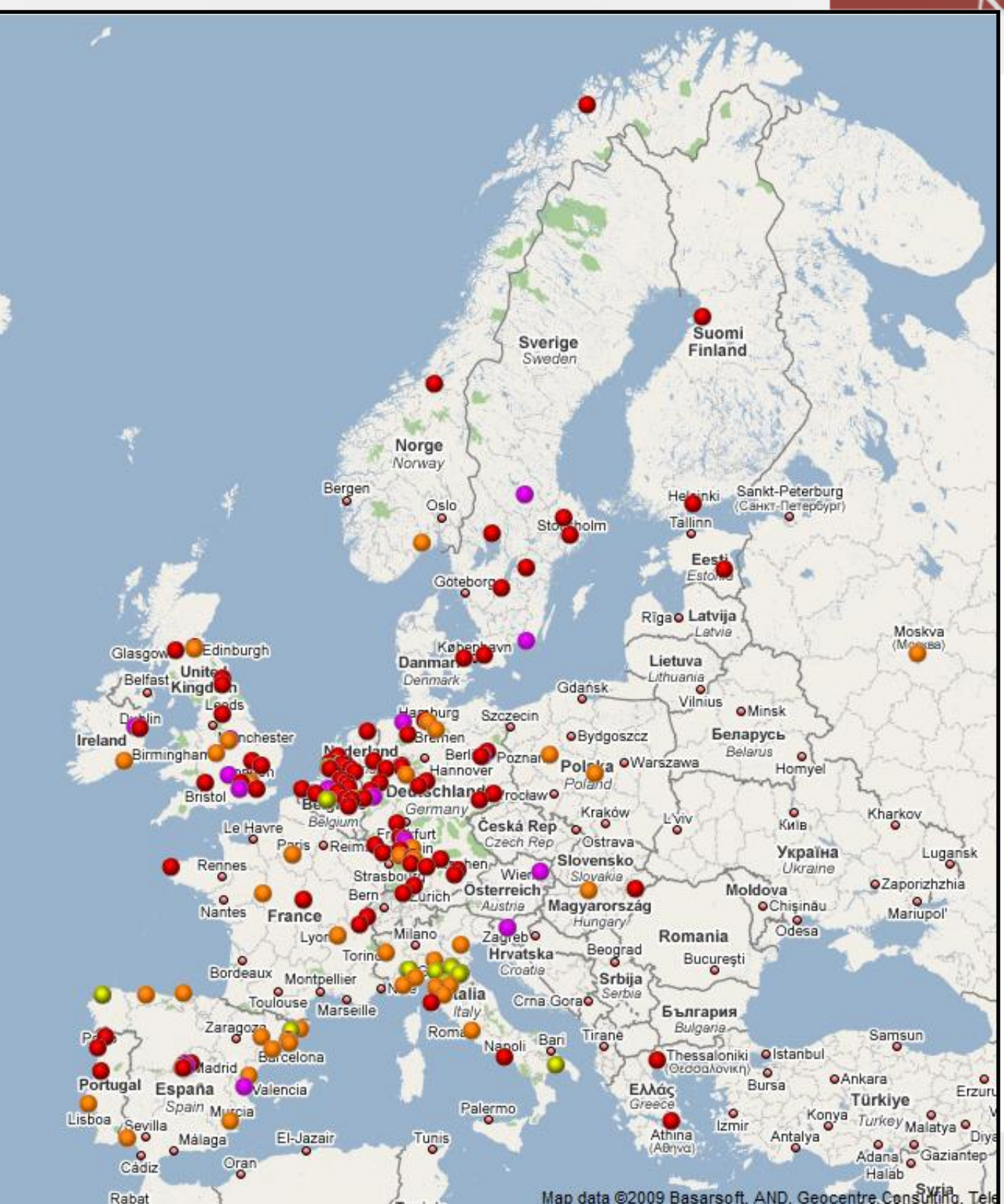




\section{Portal DRIVER}

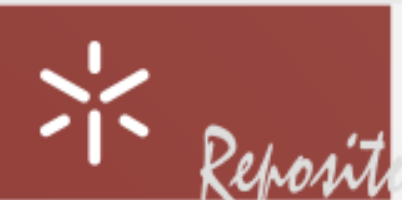

www.driver-community.eu
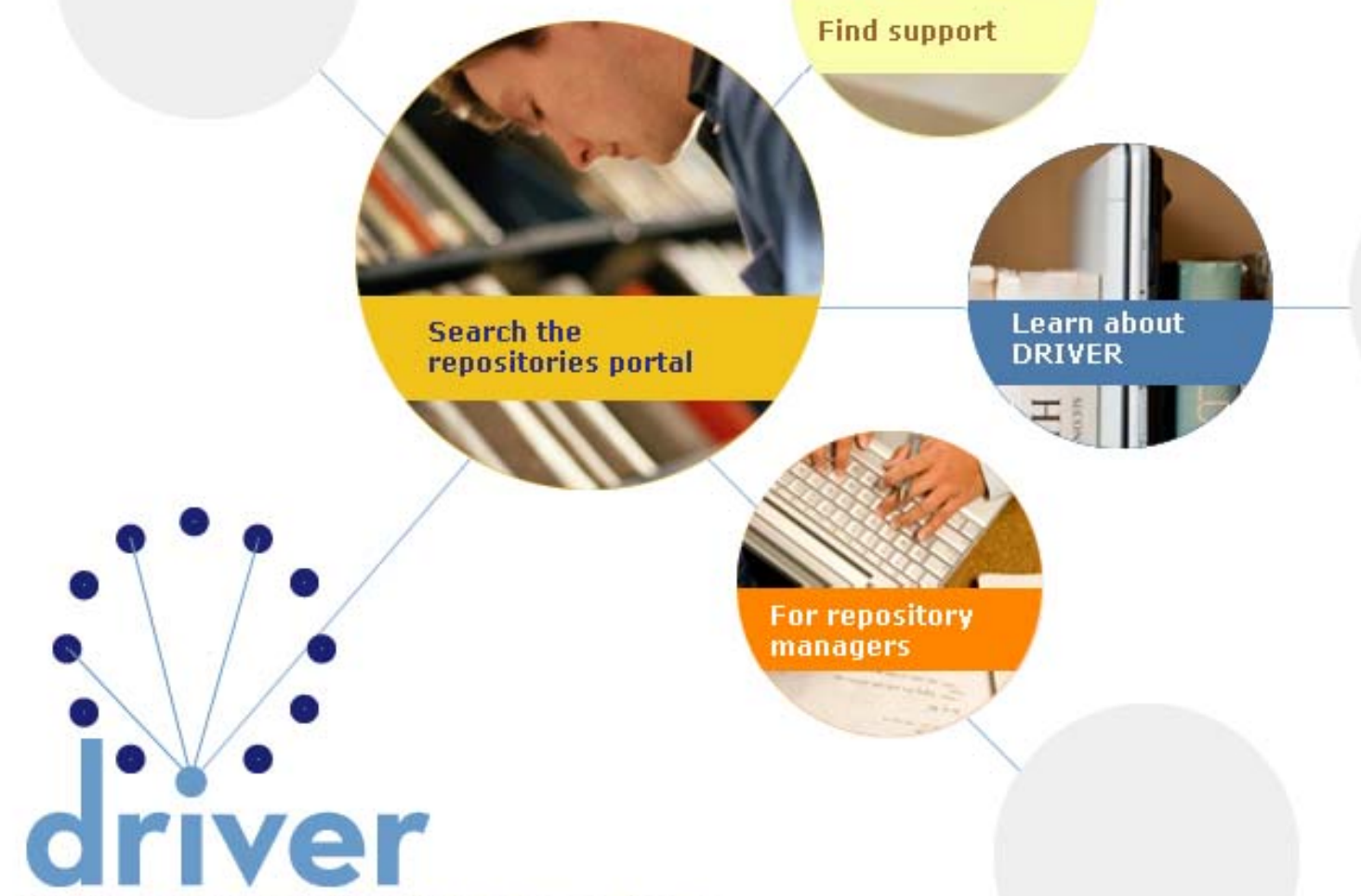

Digital Repository Infrastructure Vision for European Research

Driver is a collaboration, co-funded by the European Commission, to build a network of freely accessible digital respositories with content across academic disciplines. 


\section{Directrizes DRIVER}

- Porque são necessárias directrizes?

- Para guiar os administradores de repositórios de forma a garantir a interoperabilidade e compatibilidade com os serviços DRIVER;

- Para que os programadores de plataformas de repositórios incorporem novas funcionalidades em futuras versões 


\section{Directrizes DRIVER em vários idiomas}

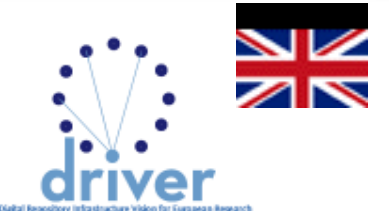

DRIVER Guidelines 2.0

Guidelines for content providers - Exposing textual resources with OAI-PMH
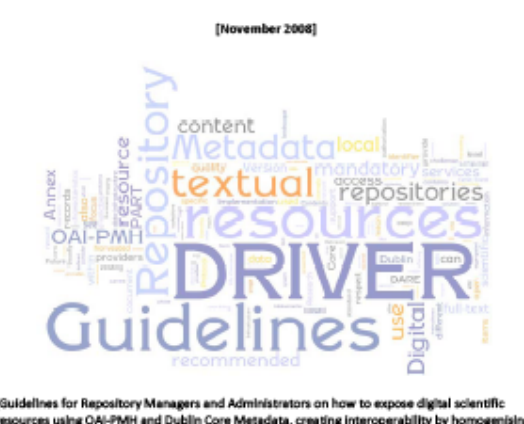

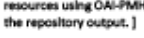

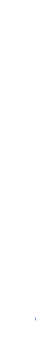

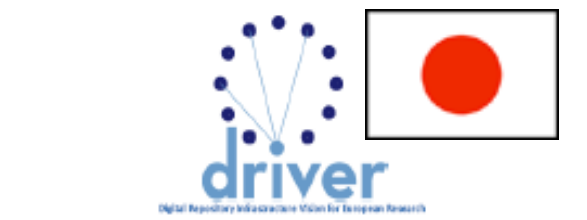

DRIVER ガイドライン

2.0

コンテンツプロバイダのためのガイドライン

OAI-PMH を使用したテキストリソースの公!

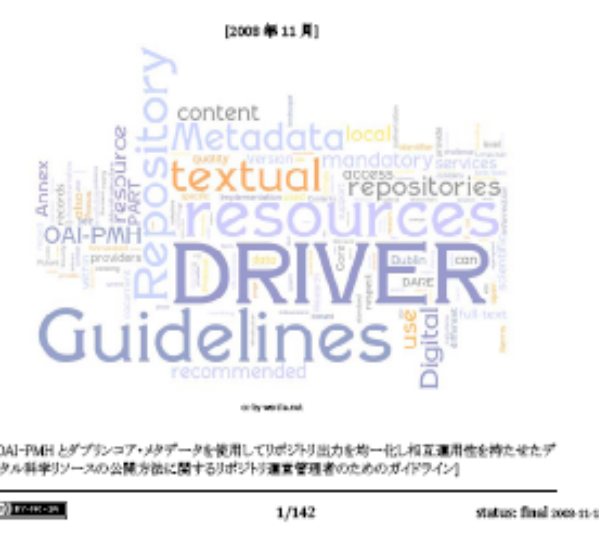

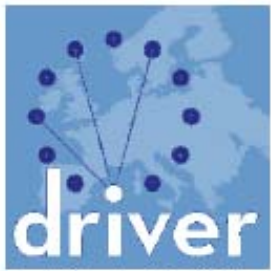

Digita/ Repository infrastucturo Vision for Europosen Research

Directrices para proveedores de contenido

\section{Exposición de recursos textuales con el} protocolo OAI-PMH

Aplicación piloto

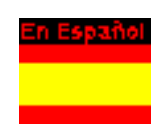

Colaboradores

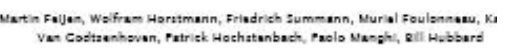

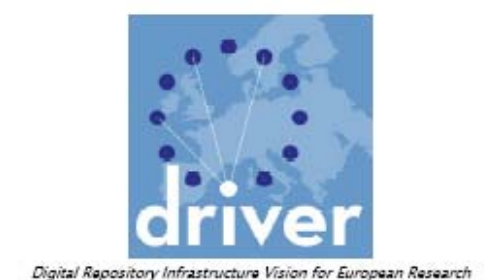

Digita/ Rapository infaztrustura Vision for Europsan Ressearch

Directrizes para fornecedores de conteúdos

Exposição de recursos textuais com o protocolo OAI-PMH

Aplicação Piloto

Varsà 1.0

Colaboradores 


\section{Confederation of Open Access}

Repositories

- Um dos resultados do projecto DRIVER II

- Nova organização. Lançada no dia 21 de Outubro, em Gent, após o DRIVER Summit que ali se realizou.

- A nova organização tem dois grandes objectivos:

- Manter em funcionamento a rede e a infraestrutura DRIVER

- Trabalhar globalmente para promover os repositórios de Acesso Livre

- Influenciando o desenvolvimento de políticas

- Fornecendo formação e orientação

- Lobying 


\section{Projecto NECOBELAC}

- NECOBELAC = NEtwork of COllaboration Between Europe and Latin American Caribbean ( LAC) é um projecto europeu para melhorar a produção e disseminação de informação científica na área da saúde publica

- O projecto NECOBELAC pretende estabelecer uma rede colaborativa entre países europeus (EU) e países da América Latina e do Caribe (LAC), para difundir conhecimentos nos métodos de escrita e publicação científica e em ferramentas apropriadas para a disseminação em acesso livre (open access) de informação para protecção da saúde pública.

- Mais informação em http://www.necobelac.eu 


\section{Projecto OpenAIRE}

- Projecto Open Access Infrastructure for Research in Europe

- Construção de infraestrutura e mecanismos de suporte para o depósito, identificação acesso e monitorização dos artigos financiados pelo FP7 e ERC.

- Criação de um sistema de Helpdesk Europeu

- Disponibilização de repósitorio para autores/trabalhos "órfãos"

- Baseado no consórcio DRIVER, alargado a todos os países europeus

- Duração 36 meses. Início em Dezembro? 


\section{Projecto RCAAP}




\section{Projecto RCAAP}

- Projecto Repositório Científico de Acesso Aberto de Portugal

- Criação de um portal nacional (metarepositório) agregando e permitindo a pesquisa nos conteúdos de todos os repositórios universitários portugueses (presentemente agrega 20 repositórios)

- Disponibilização de um serviço de alojamento de repositórios (serviço SARI que presentemente aloja 10 repositórios). 


\section{RCAAP Portal}
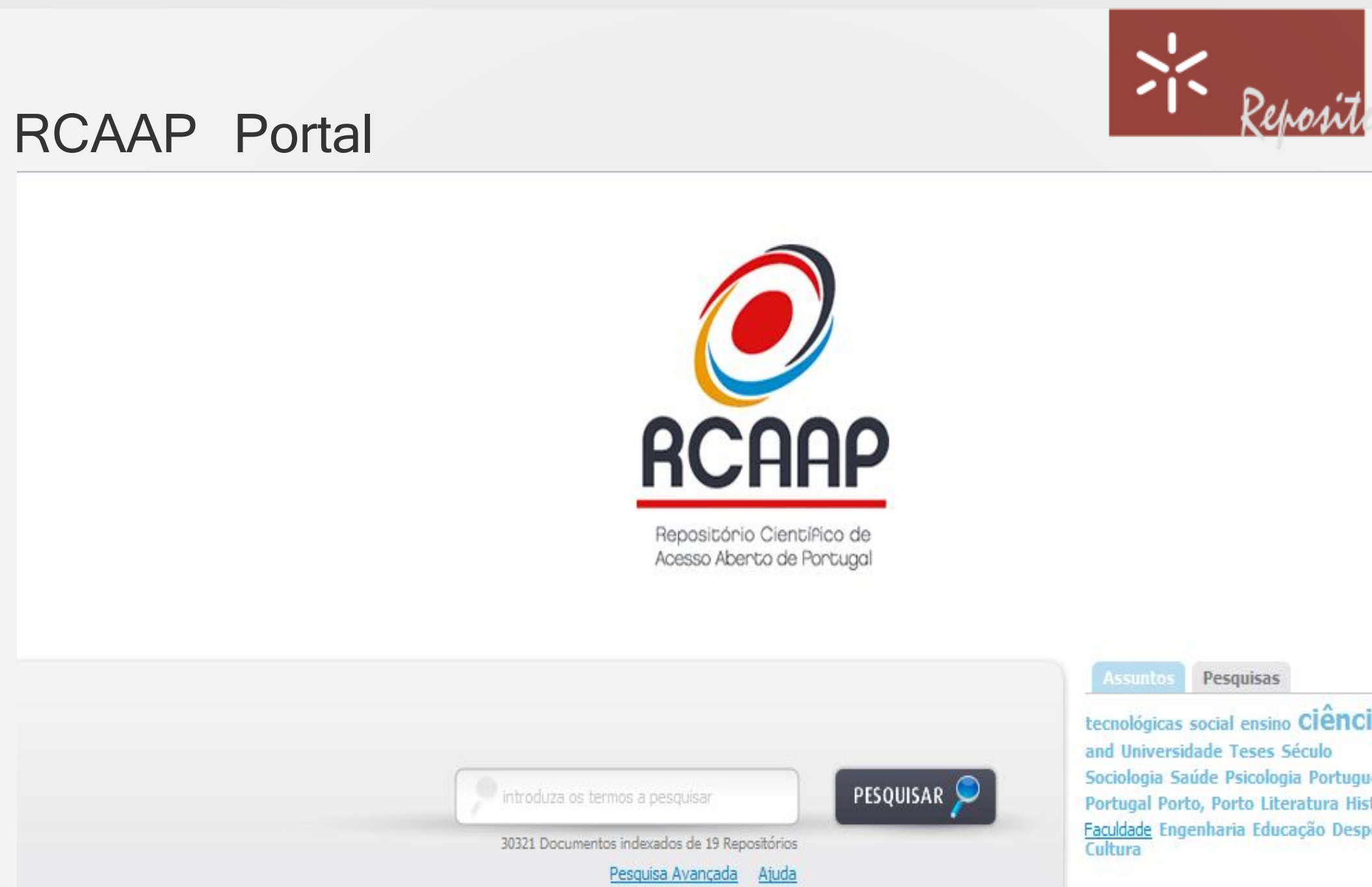

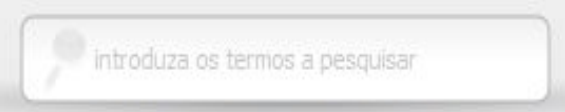

30321 Documentos indexados de 19 Repositórios Pesquisa Avancada Aiuda

\section{PESQUISAR}

9

Inglês

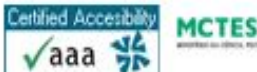
It UMM ECCN

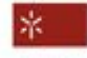

Directório Sobre o RCAAP

\section{Assuntos Pesquisas}

tecnológicas social ensino ciências and Universidade Teses Século

Sociologia Saúde Psicologia Portuguesa Portugal Porto, Porto Literatura História Faculdade Engenharia Educação Desporto Cultura 


\section{Enquadramento - Objectivos}

- Aumentar a visibilidade e difusão dos resultados de investigação

- Facilitar o acesso à informação sobre a produção científica nacional

- Integrar Portugal num conjunto de iniciativas internacionais 


\section{Enquadramento - Promotores}

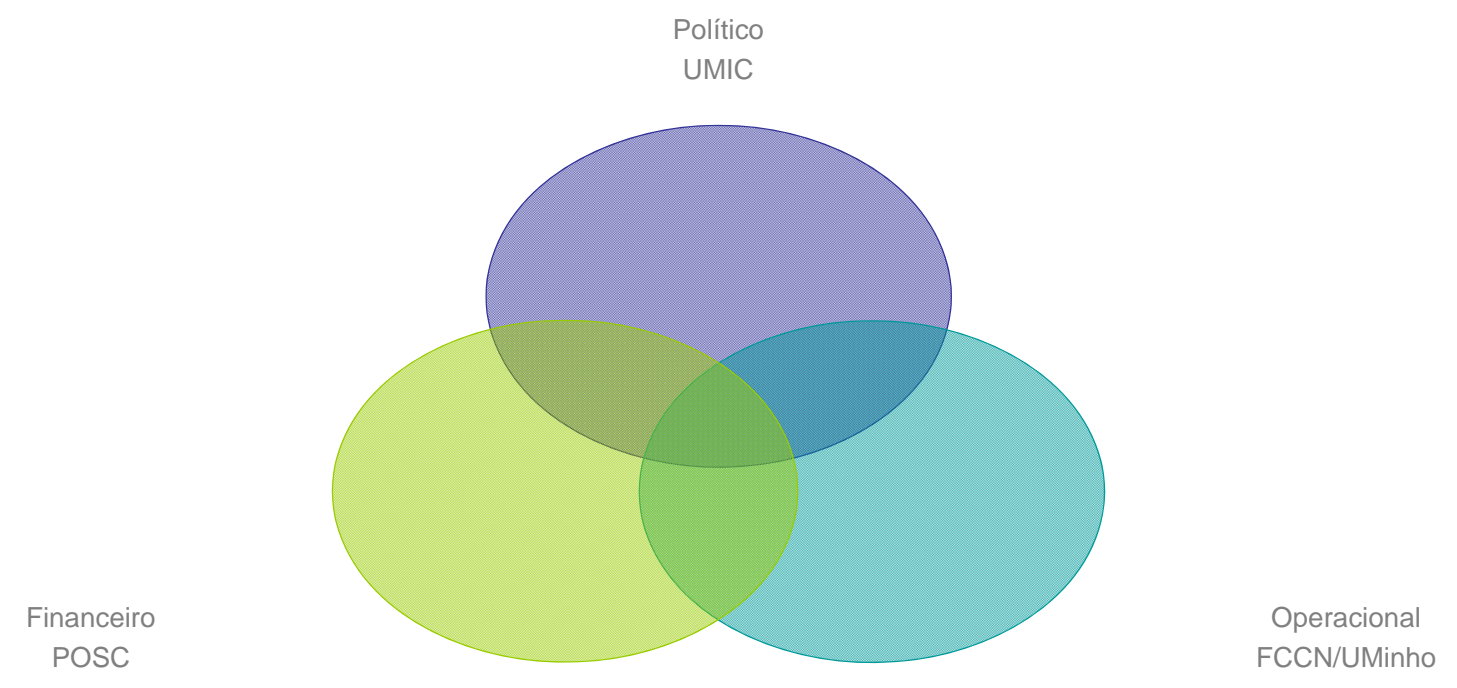




\section{Enquadramento - Equipa}

- FCCN

- João Moreira (ASA / Geral e infra-estruturas )

- João Rosa (AIA / Infra-estruturas)

- Universidade do Minho

- Eloy Rodrigues (Científica e Técnica)

- José Carvalho, Ricardo Saraiva (SDUM)

- Miguel Ferreira, João Melo (KEEP Solutions) 
Serviços

- Portal e validador RCAAP

- SARI - Serviço de alojamento de Repositório Institucional

- Repositório Comum

- Suporte

- Comunicação, disseminação e formação 


\section{Serviços - Portal e validador RCAAP}
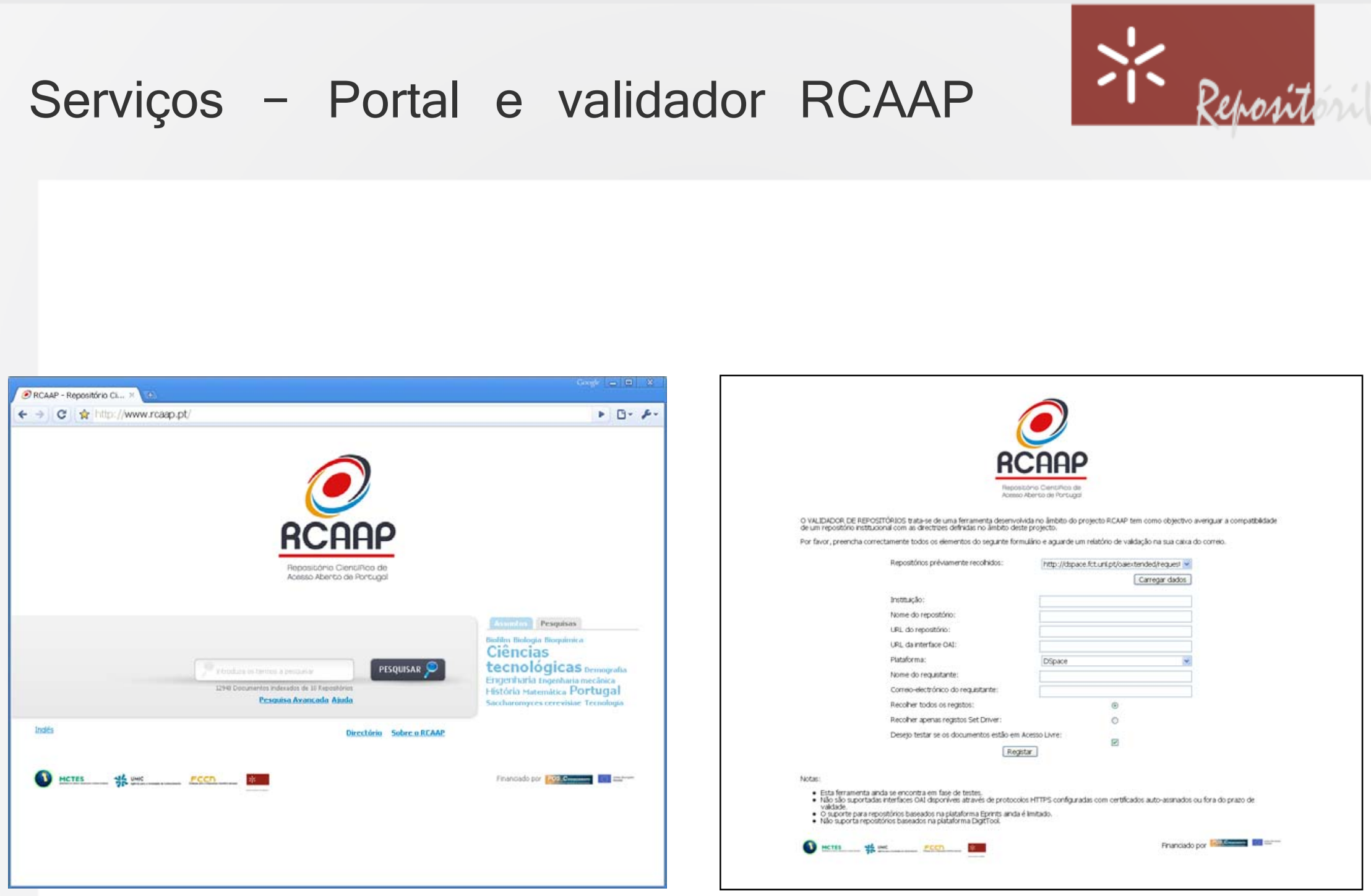
- Repositório Institucional em regime de Application Service Provider

- Destina-se a qualquer das instituições do sistema científico e do ensino superior

- Permite identidade corporativa própria

- Configurações/implementações flexíveis

- Regulado por um contrato assinado pelas partes 


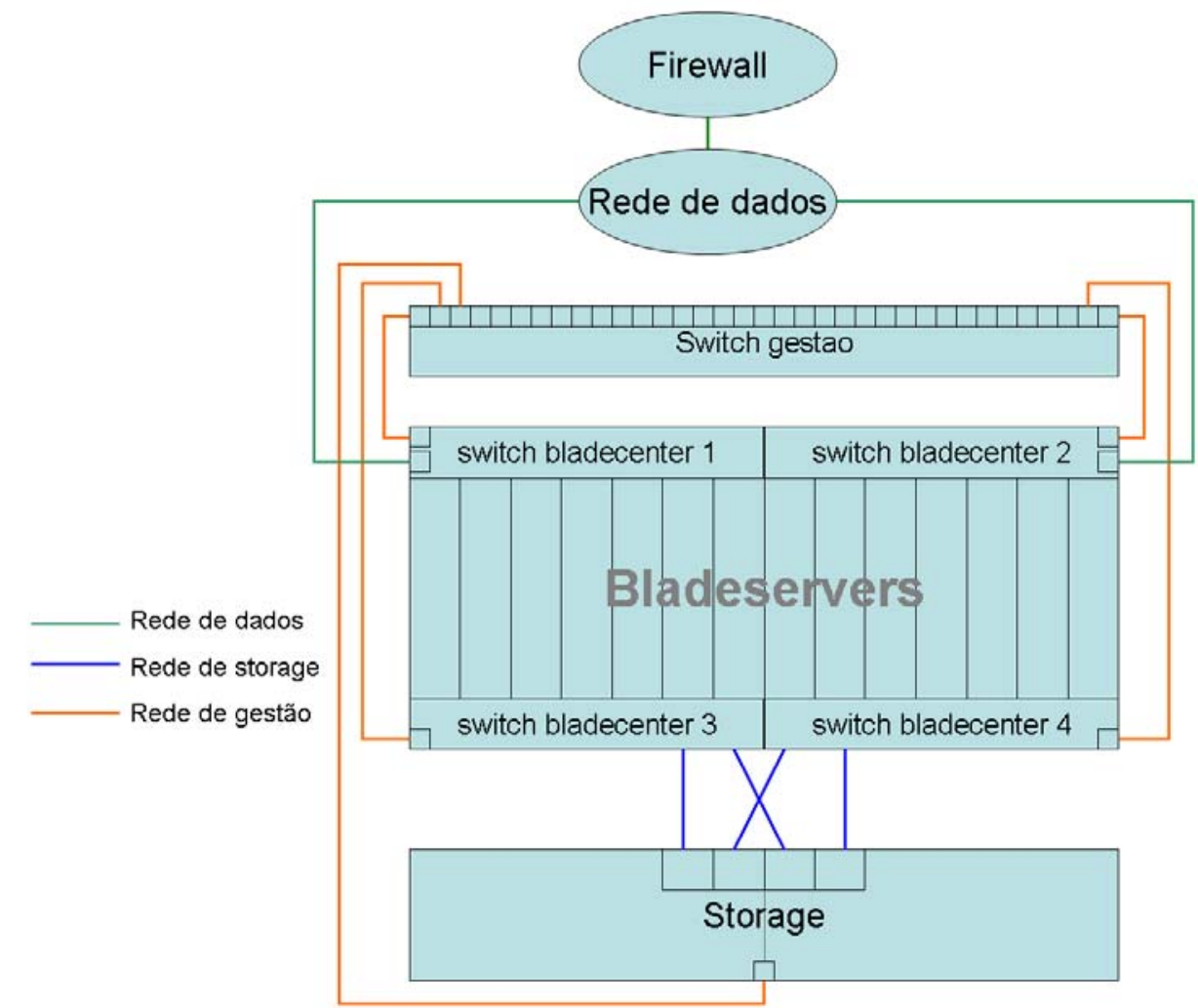

Plataforma de alta-disponibilidade Plataforma no nó central da rede da comunidade de Ensino e Investigação

Serviços de valor acrescentado

- Gestão infra-estruturas

- Gestão aplicações

- Backups

- Monitorização

- Alarmística

- Estatísticas

- SARI

- Hosting de RI até $1 \mathrm{~TB}$

- Indexação no meta-repositório nacional

- "Look and feel" institucional 
Serviços - Suporte

- Apoio na gestão dos SARls

- Apoio na gestão do harvest para o RCAAP

- Aconselhamento e missões OA 
Comunicação, Disseminação e Formação

- C1 -Divulgação do Portal RCAAP

- C2 -Sensibilização e Divulgação OA, repositórios e SARI

- C4 -Formação de gestores e administradores de repositórios 
Divulgação do Portal

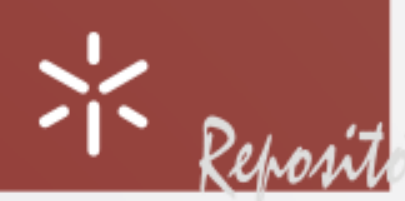

- Plano de Divulgação

- Cartaz

- Desdobrável

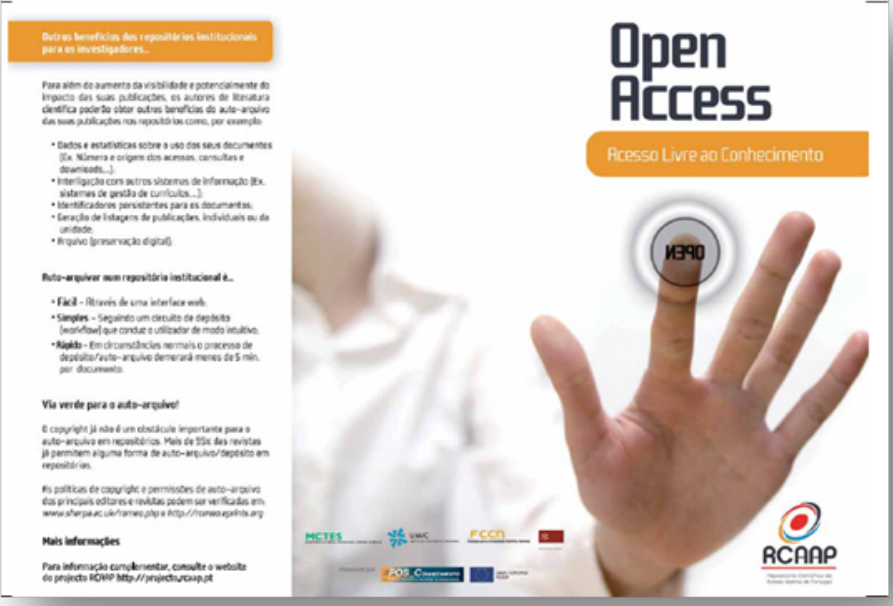

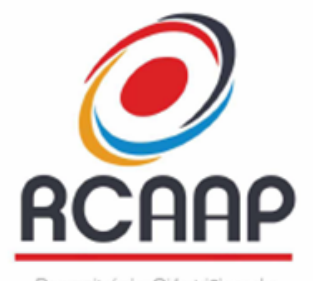

Repositúnio Cléntíifico de

o lugar do saber

Q Pesquisar

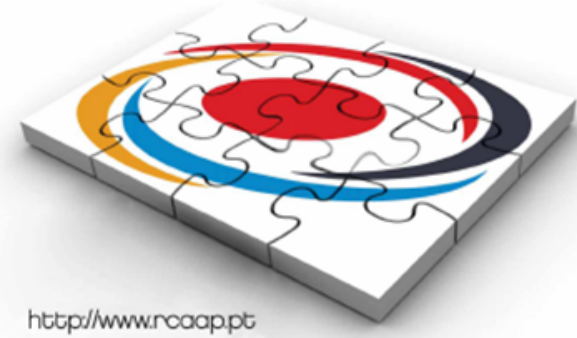

MCTIS 类些 ECCD - 


\section{Web 2.0}

- Blog - http://blog.rcaap.pt

- Twitter - www.twitter.com/rcaap

- Facebook - www.facebook.com/rcaap

- Website Projecto http://projecto.rcaap.pt 


\section{Serviços - Formação}

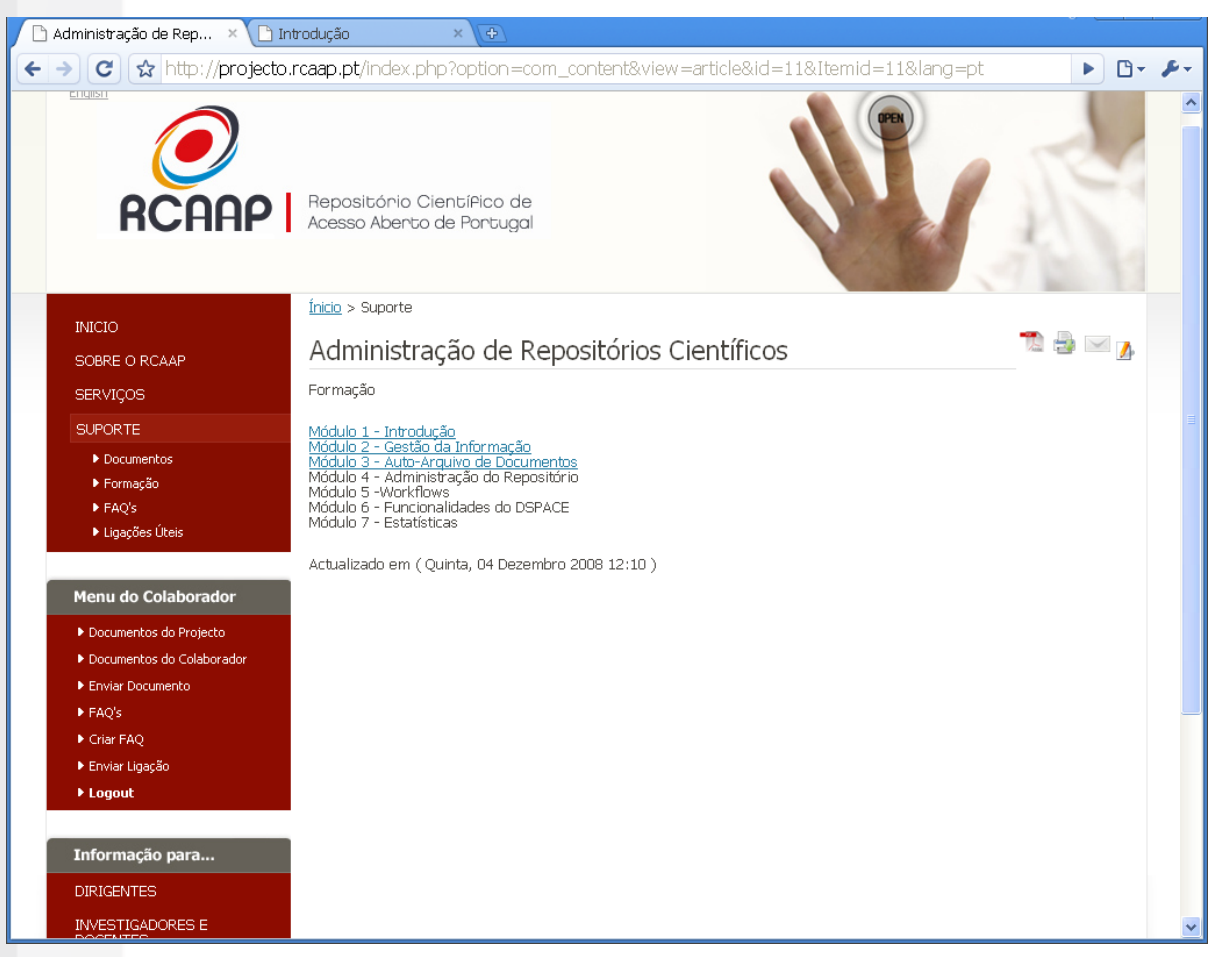

E-learning

- M1 - Introdução

- M2 - Gestão da Informação

- M3 - Auto-Arquivo de Documentos

- M4 - Administração do Repositório

- M5 -Workflows

- M6 - Funcionalidades do DSPACE

- M7 - Estatísticas

- Formação em sala 


\section{Indicadores - Total documentos MR}

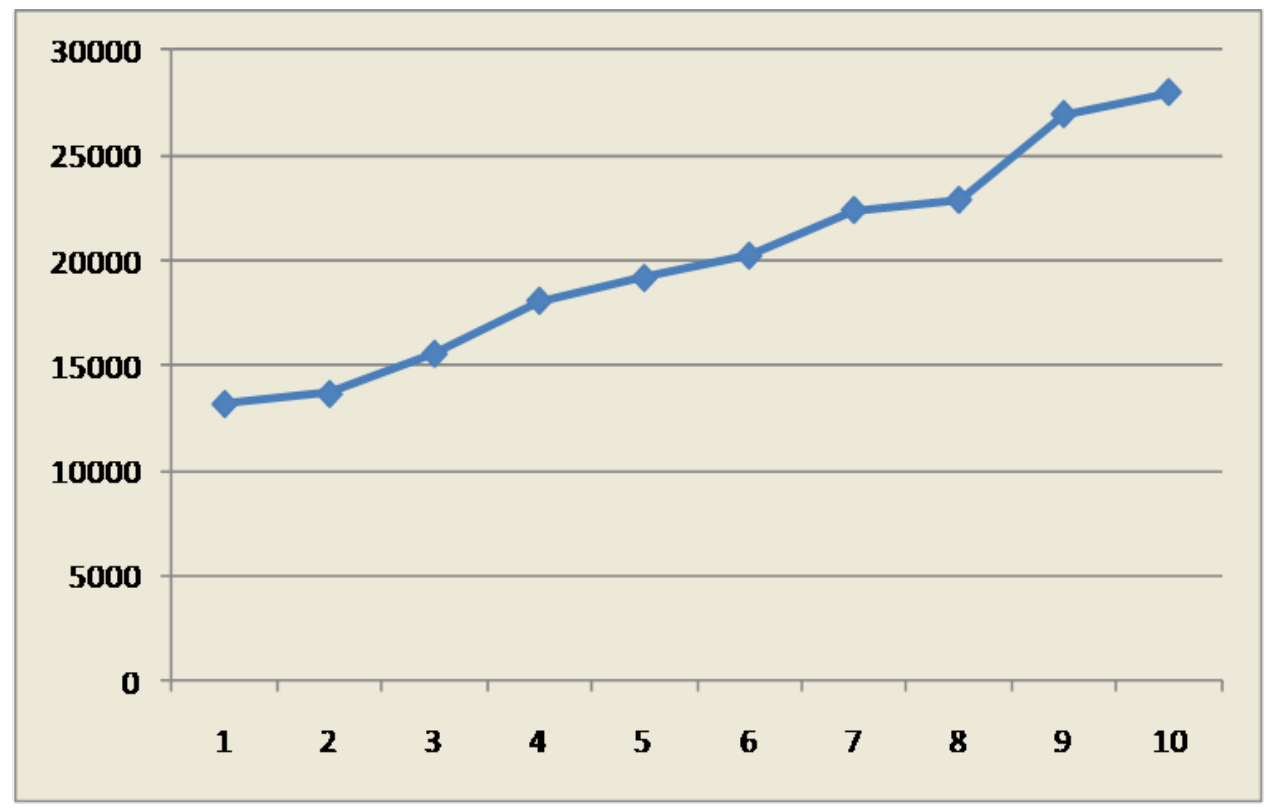


4a Conferência Open Access

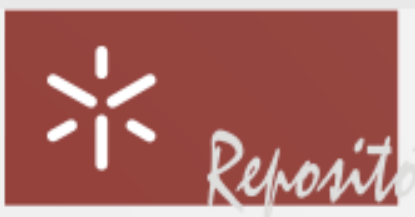

Universidade do Minho, Braga, 26 e 27 de Novembro de 2009

http://confoa09.sdum.uminho.pt/ 
O que o ganhou a U.M. com a sua política

- Maior visibilidade e impacto para a sua produção científica e para a Universidade como um todo

- Reconhecimento na comunidade nacional e internacional do Open Access e dos repositórios que se traduziu, entre muitas outras coisas, em oportunidades para participar em projectos europeus e para coordenar técnica e cientificamente o projecto RCAAP 


\section{Dúvidas? Questões?}

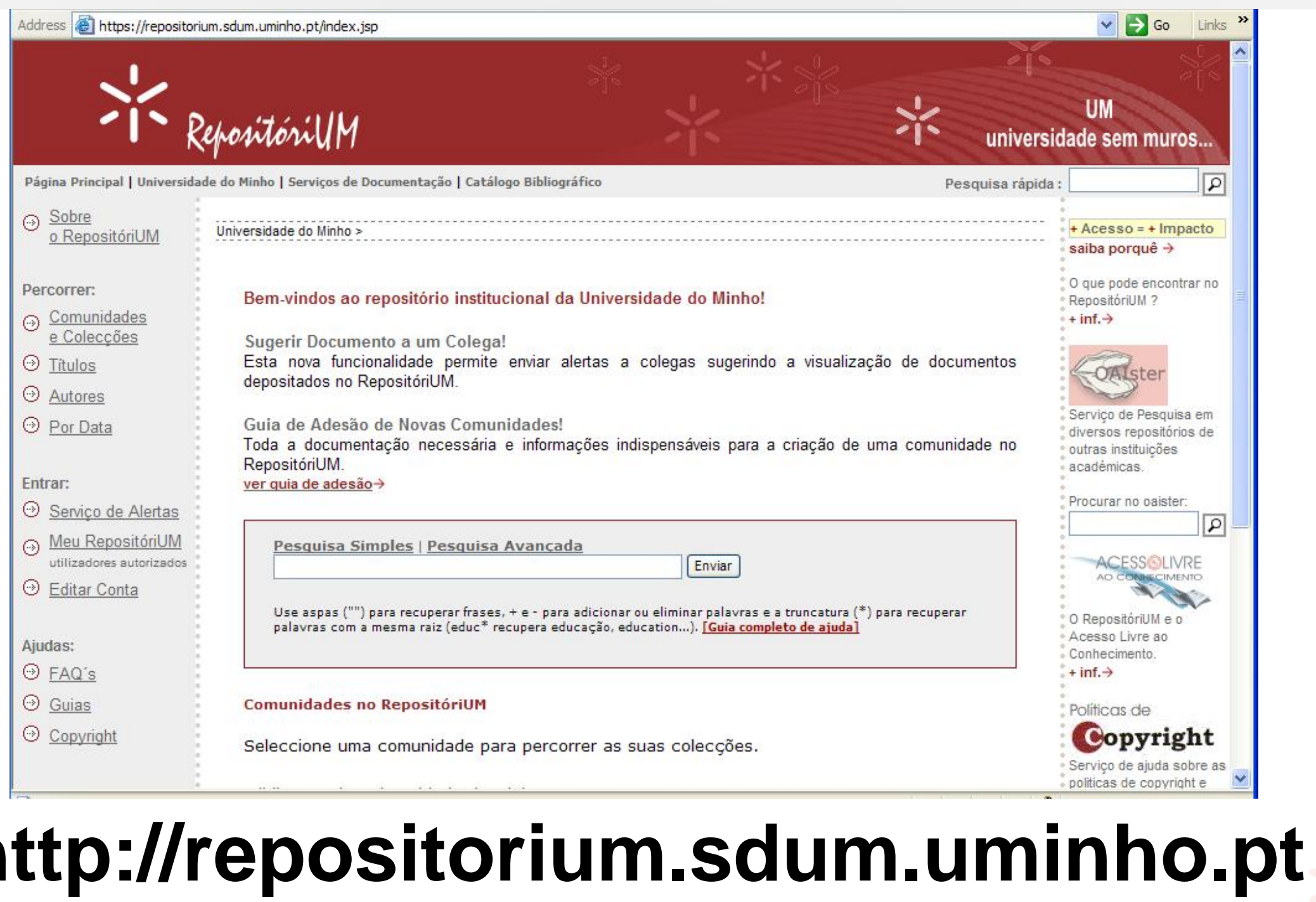




\section{Contactos}

eloy@sdum.uminho.pt

http://cibertecario02.blogspot.com

http://www.twitter.com/cibertecario02 